\title{
20. PETROPHYSICAL RESULTS FROM LOGGING IN DSDP HOLE 395A, ODP LEG 1091
}

\author{
Daniel Moos²
}

\begin{abstract}
Analysis of geophysical logs recorded during Leg 109 of the Ocean Drilling Program within the interval 112-606 $\mathrm{m}$ below seafloor (mbsf) in DSDP Hole 395A provides a detailed look at crustal properties in relatively young (7.3 $\mathrm{Ma}$ ) oceanic crust produced at the slow-spreading mid-Atlantic Ridge. Based on log response, the interval can be divided into two sections. Above $500 \mathrm{~m}$, occasional high densities, velocities, and resistivities indicate the presence of thin flow units, of which the intervals 184-192 and 194-202 mbsf are prominent examples. Otherwise this upper section is composed of a series of thick pillow units, characterized by high porosities and low velocities and resistivities near their tops, with steadily decreasing porosities and increasing velocities and resistivities with depth. These trends, primarily observed in the phyric units, delineate the boundaries between the chemical units identified in the cores. Porosity in the uppermost section varies between core values of less than $5 \%$ and estimates from sonic measurements of more than $20 \%$. Below $500 \mathrm{~m}$, velocities and resistivities are quite high and uniform, and porosities are low. This lower unit has an average compressional velocity of $5.12 \mathrm{~km} / \mathrm{s}$ and shear velocity average of $2.73 \mathrm{~km} / \mathrm{s}$; $\mathrm{V} p / \mathrm{V} s$ averages 1.88 , suggesting the presence of many microcracks. The average porosity in this lower interval is less than $10 \%$. Gamma activity is very low throughout the basement section. However, systematic variations in potassium correlate with porosity in the shallower section. Although the presence of a $\sim 150$-m-thick Layer $2 \mathrm{~A}$ cannot be ruled out on the basis of these measurements, the similarity between average core velocities and seismic velocities measured nearby, which do not show this layer, suggests that it is not present, or if present is laterally discontinuous. Finally, the systematics of differences between porosities determined from resistivity and velocity suggest that large-scale porosity in situ is electrically discontinuous, and implies that high permeabilities are constrained to narrow zones in the crust.
\end{abstract}

\section{INTRODUCTION}

Hole 395A was drilled during DSDP Leg 45 to a total depth of 664 mbsf into 7.3 Ma crust approximately $110 \mathrm{~km}$ west of the mid-Atlantic Ridge (Fig. 1). The borehole is situated on the edge of a small sediment pond near the center of magnetic anomaly 4 , at $22^{\circ} 45^{\prime} \mathrm{N}$ latitude. Hole $395 \mathrm{~A}$ penetrates $93 \mathrm{~m}$ of sediments and $571 \mathrm{~m}$ of basement. The uppermost $112 \mathrm{~m}$ were cased. Well-bore instabilities at a brecciated dolerite zone caused loss of the hole below that depth, leaving the bottom of the hole at $609 \mathrm{mbsf}$. Therefore, only the remaining $497 \mathrm{~m}$ of basement (from $112 \mathrm{mbsf}$ to $609 \mathrm{mbsf}$ ) were still available for downhole measurements at the end of Leg 45 drilling.

This borehole, along with DSDP Holes 418A and 504B, has been the target of a comprehensive series of in situ geophysical investigations designed to augment data from the recovered cores and to provide insights into the characteristics of the shallow oceanic crust as a function of age and spreading rate. Downhole measurements were made in Hole 504B during DSDP Legs 69 and 70 (see Cann, Langseth, Honnorez, Von Herzen, White, et al., 1983) and Leg 83 (see Anderson, Honnorez, Becker, et al., 1985), and Hole 395A was logged during DSDP Leg 78B (see Hyndman, Salisbury, et al., 1984), to provide continuous measurements of compressional-wave velocity, density, porosity, resistivity, and natural radioactivity as a function of depth in holes drilled into young oceanic basalt. A similar measurement suite was recorded in DSDP Hole 418A during ODP Leg 102 (see Salisbury, Scott, et al., 1986). On ODP Leg 109 , DSDP Hole 395A was reoccupied to repeat the measurements made during DSDP Leg 78B and to augment those results by adding sonic full waveform and geochemical measurements.

${ }^{1}$ Detrick, R., Honnorez, J., Bryan, W. B., Juteau, T., et al., 1990. Proc. ODP, Sci. Results, 106/109: College Station, TX (Ocean Drilling Program).

${ }^{2}$ Stanford University, Stanford, CA 94305.
In this paper I will present the principal logging results from ODP Leg 109 in light of present knowledge about the changes due to alteration of the basaltic crust and seismic measurements near the borehole. In formulating the discussion the primary log curves, including electrical resistivity, sonic velocity, gamma-gamma density, natural gamma radiation, and the measured potassium content, will be presented. In this context a corrected density log (Greenberg, 1988) will serve as an upper bound on true formation density. Velocity measurements obtained from the standard log of sonic traveltimes using a correction algorithm, and from full waveform multichannel sonic (MCS) logs will both be used in this study. I also present an analysis of borehole televiewer (BHTV) data recorded during DSDP Leg 78B (Hickman et al., 1984a). Finally, the aggregate log results will be compared to other geophysical results in the Site 395 area and to models of lithospheric development.

\section{CORE DESCRIPTIONS}

Core recovery during drilling of Hole 395A on DSDP Leg 45 was extremely low, ranging from less than $6 \%$ in a sedimentary breccia at the top of basement (now largely behind casing) to $32 \%$ in the interval $174-210$ mbsf (Melson, Rabinowitz, et al., 1979). Figure 2 shows the basement lithostratigraphy based on core analyses (after Melson, Rabinowitz, et al., 1979). The rocks cored in this hole are mostly basalts, although very small amounts of gabbros and peridotites were encountered in the interval 172.4-174.3 mbsf. The basalts were divided into phyric and aphyric units. The aphyric units are classic olivine tholeiites (Rhodes et al., 1979), whereas the phyric units were categorized as plagioclase tholeiites. $\mathrm{K}_{2} \mathrm{O}$ was less than $0.2 \%$ in both types. Although increased $\mathrm{K}_{2} \mathrm{O}$ content generally was presumed to result from seawater alteration, it was not necessarily correlated to increased water content or oxidation state. 


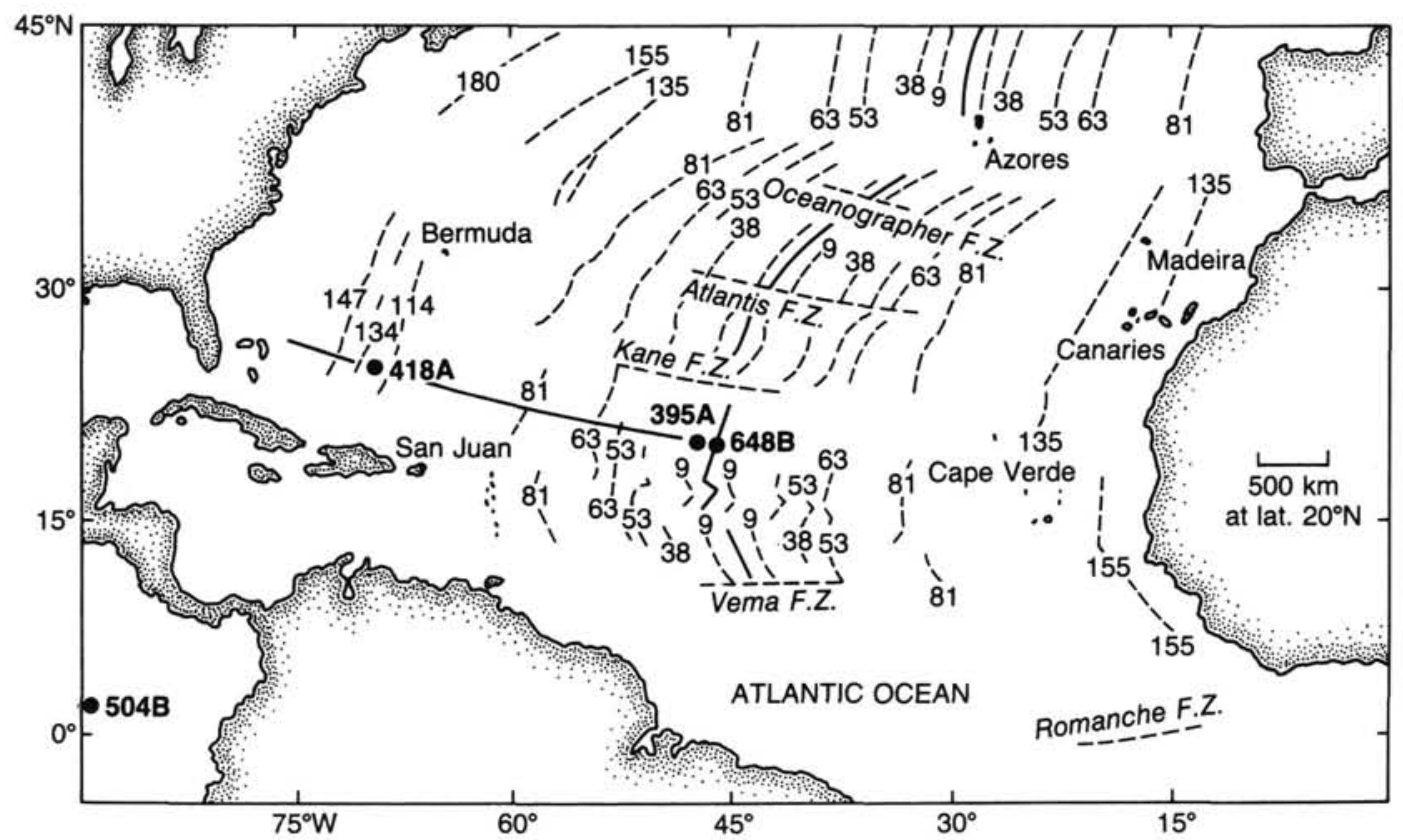

Figure 1. Map showing DSDP Sites 395 (7.3 Ma) and 418/417 (110 Ma), and ODP Site 648 (zero-age), after Shipboard Scientific Party (1988a). These three sites lie along the same spreading line, and it is therefore assumed that the basaltic crust at each site was produced at a different time at the same point on the mid-Atlantic Ridge.

All of these materials have been altered to some degree by interaction with seawater. The predominant alteration occurred at low temperatures, with carbonate veins, smectites (usually saponite), zeolites, goethite, opal, and gypsum present in decreasing order of abundance (Lawrence et al., 1979). Veins with carbonate or other filling, altered basalt glass, and filled vesicles were common. Olivine was sometimes altered in place, although associated plagioclase and pyroxene was generally quite fresh (Juteau et al., 1979). In a companion hole (395) alteration in the basalts was observed to correlate with decreased density and velocity and increased $\mathrm{K}_{2} \mathrm{O}$.

Core physical properties are described by Melson, Rabinowitz, et al. (1978). Measured porosities range from $2.2 \%$ to more than $13 \%$, although the porosities tended to cluster, generally being either below $5 \%$ or more than $8 \%$. Modal porosity was somewhat less than $5 \%$. Bulk densities ranged from 2.7 to more than $2.9 \mathrm{~g} / \mathrm{cm}^{3}$ and were also bimodally distributed. A simple linear fit to the density/porosity data yields a grain density (zero-porosity intercept) of approximately $2.96 \mathrm{~g} / \mathrm{cm}^{3}$. Velocities had a similar bimodal distribution, with values either between 5.4 and $6.0 \mathrm{~km} / \mathrm{s}$ or below 5.0 $\mathrm{km} / \mathrm{s}$. The high-density/low-porosity/high-velocity materials were generally less altered than the samples with lower densities and velocities and higher porosities.

\section{LEG 78B LOGGING}

During DSDP Leg 78B a set of geophysical logs was recorded in Hole 395A from the bottom of casing at $112 \mathrm{mbsf}$ to a depth of $609 \mathrm{mbsf}$ ( $506 \mathrm{~m}$ below the sediment-basement contact). The principal results are presented in Figure 3 (after Mathews et al., 1984). The density and neutron porosity logs were considered to be extremely suspect, as logging conditions were quite poor and hole size and surface roughness degraded the log response. Velocities were also considered suspect, except perhaps in the lowest $60 \mathrm{~m}$ of the hole. Even there, however, the average compressional velocity of 5.4 $\mathrm{km} / \mathrm{s}$ was still considered to be too low, based on a comparison to velocities measured on core samples (Hyndman and
Salisbury, 1984). A systematic correlation between the gamma-ray log and core potassium content suggested that the gamma $\log$ was reading correctly, although its sensitivity may have been somewhat low.

Caliper measurements of hole size were obtained during the density logging run with a two.arm caliper probe. This type of caliper tool typically records the largest borehole cross-section (Serra, 1984), and thus tends to overestimate the average borehole radius. A comparison of this measurement with a hole size measurement obtained from the televiewer data is presented below.

All of the logs were affected by the large hole size and by the surface roughness of the cored basalt. As the hole was drilled with a $9.875-\mathrm{in} .(25.1-\mathrm{cm})$ bit, the $28-\mathrm{cm}$ minimum hole size recorded by the caliper indicates that even in the best parts of the hole some enlargement has taken place. Severely enlarged zones occur at 160-180, 200-240, $300-330,415-430,500-510$, and $555-565 \mathrm{mbsf}$. These zones generally have lower measured densities and resistivities and higher porosities. The deepest interval, within which the sonic results are most reliable, coincides with a decrease in hole size.

There are two reasons for these correspondences. The first is that the logs are strongly affected by hole size. Under this hypothesis one can perhaps be justified in "correcting" all of the logs for hole size by removing that portion of the measured value which is linearly or otherwise (depending on the physics of the measurement) correlated to the caliper. However, the correspondence between caliper and the other measurements is also quite likely to be a real phenomenon due to the mechanical properties of the rock, as the drilling process will preferentially enlarge those zones with higher porosities (and hence lower densities, resistivities, and sonic velocities) due to their lower inherent strength. In correcting the density log recorded during ODP Leg 109 , Greenberg (1988) essentially assumed that all hole size effects are linear and correctable, which results in a maximum possible bound on the true formation density. 


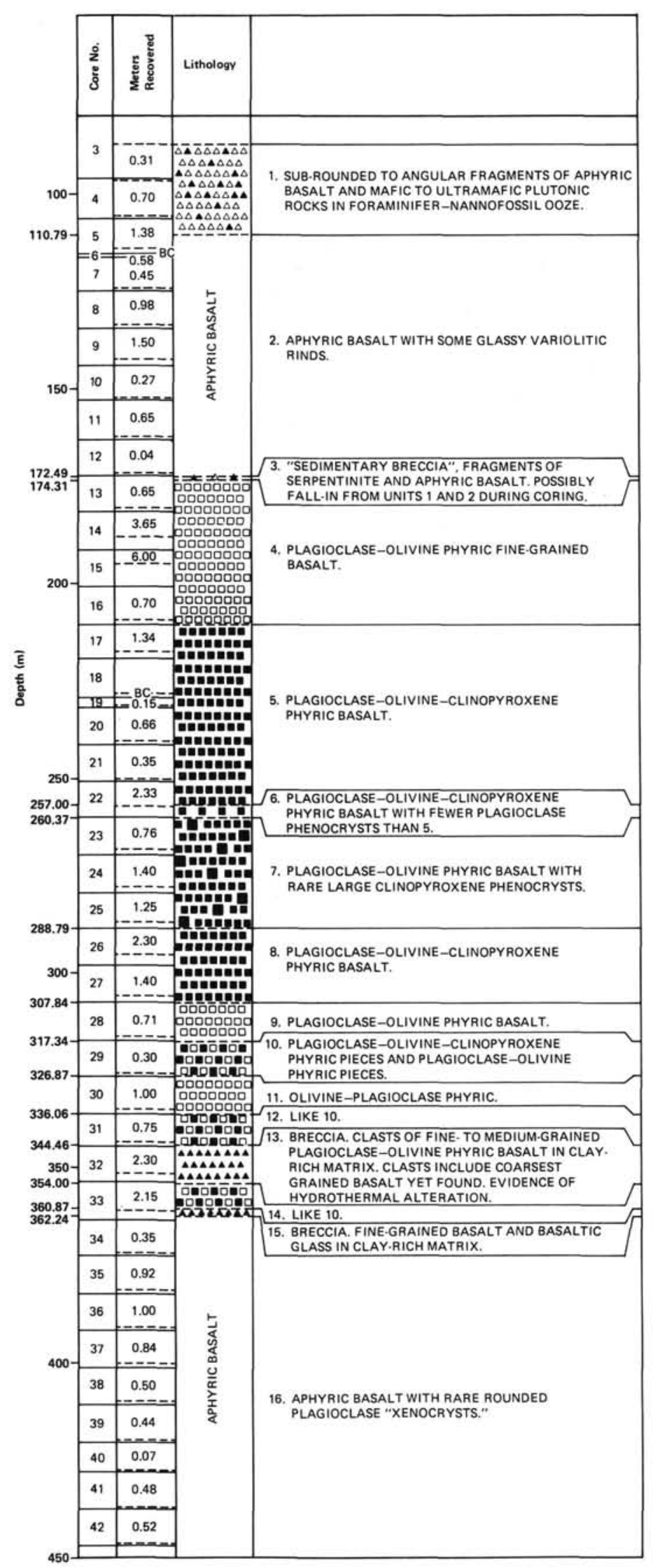

Figure 2. Principal lithologic units in DSDP Hole 395A from analyses of the recovered core, after Melson, Rabinowitz, et al. (1979).

\section{THE LEG 78B BOREHOLE TELEVIEWER LOG}

The borehole televiewer is an acoustical well-logging device containing a transducer that fires a high-frequency pulse at the borehole wall and receives the reflected return signal (see Zemanek et al., 1970). The transducer fires about 1800 times per second. It is mounted on a shaft which rotates at a nominal $3-\mathrm{Hz}$ rate, resulting (as the tool is pulled up the hole) in an image composed of 600 reflections per revolution. The reflected amplitude is displayed as a function of azimuth and depth in the hole by photographing the trace of a three-axis oscilloscope. The horizontal resolution is determined by the rotation rate. The vertical sample density is a function of both the logging rate and the rotation rate. When run normally at about $1.5 \mathrm{~m}$ per minute the tool heavily oversamples in the horizontal plane (almost 2 reflections per degree of azimuth) and repeats its scan only once per centimeter along the axis of the hole. The picture can be oriented using a flux-gate to detect the time when the transducer passes magnetic north. Thus the image produced is an oriented picture of the inside of the wellbore, sliced open at magnetic north and laid flat. The orientation at any reflected signal is determined by the difference between the time of the last north pulse and that of the signal.

Recent developments in BHTV digital processing (Barton, 1988) developed for ODP Wireline Logging now allow the determination of both traveltime and amplitude of the reflected signal, as a function of depth and orientation in the borehole. These methods take advantage of the fact that the time of flight of BHTV acoustic pulses from the transducer to the borehole wall and back depends only on the size of the hole and the velocity of the fluid in the borehole. If the tool is reasonably well-centered in a cylindrical well-bore, reflections are returned from the entire $360^{\circ}$ sweep. If the tool is badly off center or the hole is very elliptical, dark bands resulting from lost data due to the non-normal incidence of the acoustical pulse are generated (see Georgi, 1985). These typically occur closely spaced at equal angles from the azimuth where the tool is closest to the borehole wall, if the tool is off center in a cylindrical hole or at angles bisecting the principal axes of the hole, if the hole is elliptical and the tool is centered. More complicated patterns develop as the geometry becomes more complex.

During DSDP Leg 78B a borehole televiewer log was obtained throughout the open-hole section of Hole $395 \mathrm{~A}$ (Hickman et al., 1984a). However, the high pressures and low temperatures at depth in the hole increased the viscosity of the oil in the tool, causing an extremely low rotation rate. This had the effect of reducing the vertical sampling rate from about one scan per centimeter to about one scan per inch (or less) and caused the rotation to become highly erratic. Thus the azimuth of the transducer at an arbitrary time was no longer a simple function of the time since the previous north pulse detection. Furthermore, the low rotation speed caused loss of data in the photographic images, as the sweep across the oscilloscope screen used to produce the image reached its maximum deflection before the transducer had completed one rotation. In consequence, Hickman et al. (1984a) restricted their analysis of the data to a comparison of the average reflectivity (determined by using a light-meter on photographs of the BHTV image) with caliper hole size and core lithology. The reflectivity was high where competent rocks were encountered, and low in rubble or washed-out zones.

To improve the quality of the televiewer images and to study quantitatively the shape of the borehole, the BHTV data were digitized using techniques described by Barton (1988). The resulting images were somewhat improved relative to the 


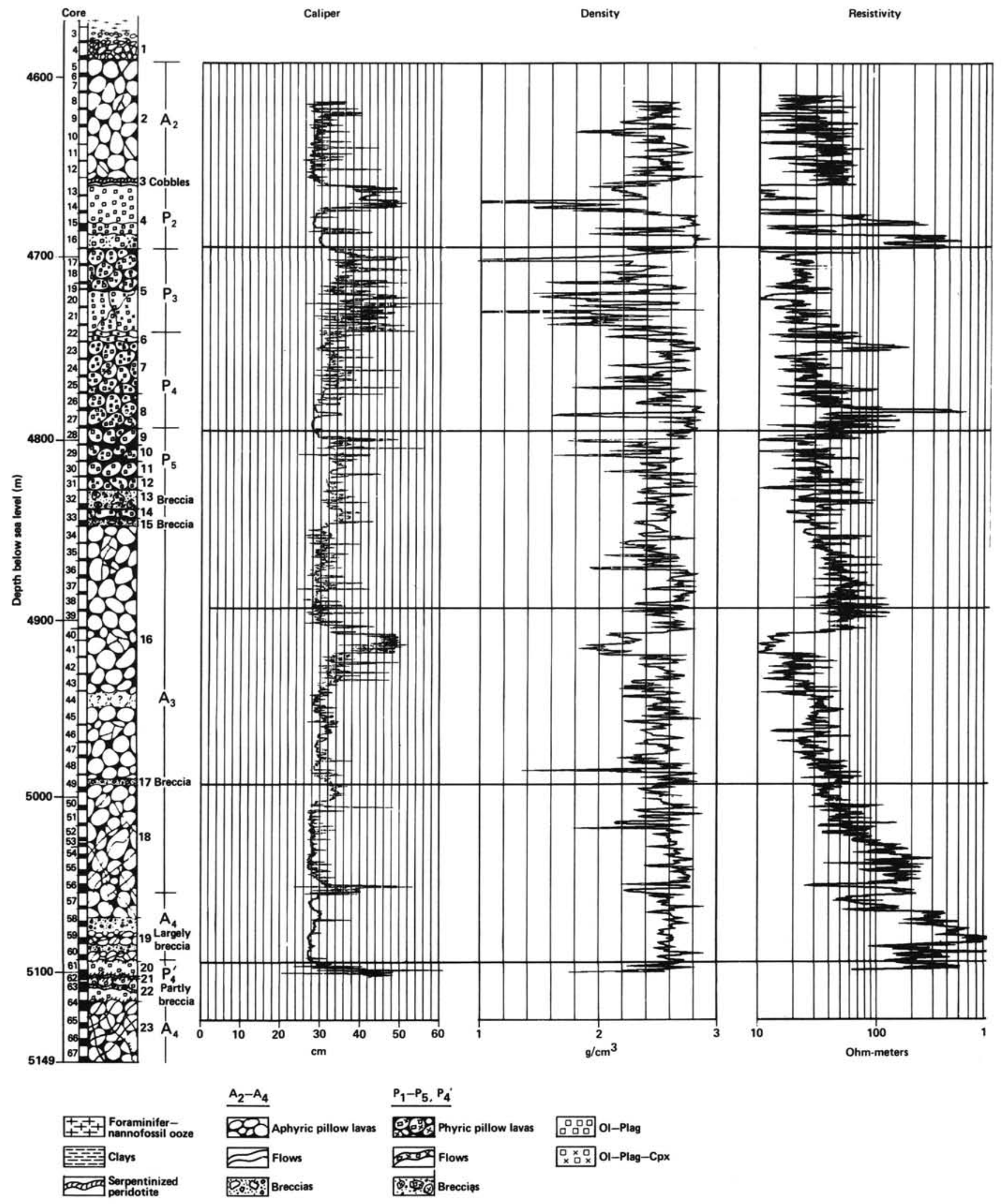

Figure 3. Geophysical logging results from Leg 78B, showing hole size, gamma-gamma density, electrical resistivity, sonic compressional-wave velocity, neutron porosity, and natural gamma intensity, after Mathews et al. (1984). 


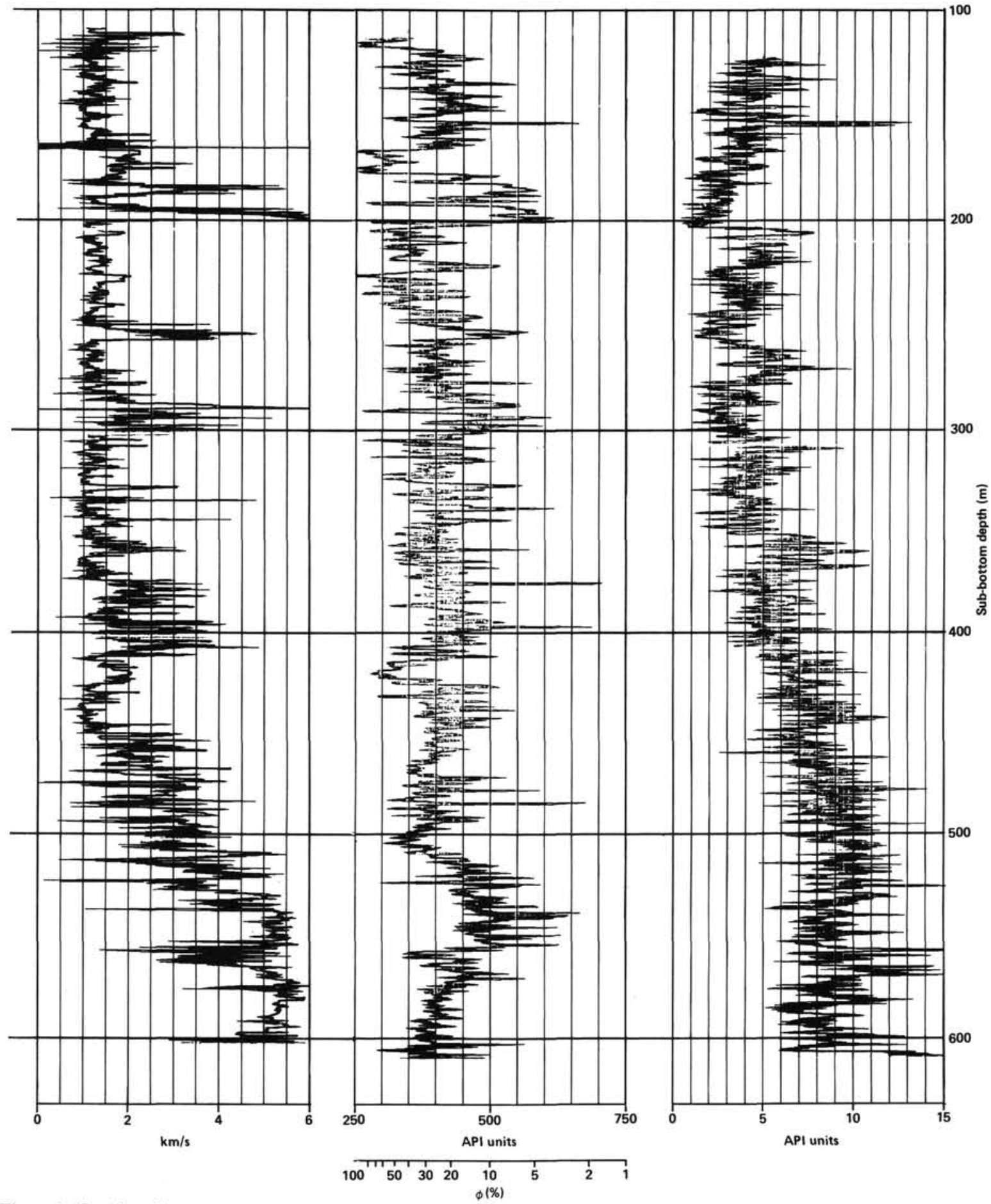

Figure 3 (Continued).

photographs, but no corrections for ship heave or the variable rotation rate could be made, and thus lithologic features could not be resolved even in the digitized images. However, quantitative determinations of hole size and reflectivity were made, and are presented in Figure 4 along with a reproduction of Hickman et al.'s (1984a) results. The average reflectance is quite similar in both curves and shows a similar inverse correlation to hole size. The televiewer traveltime data were converted to borehole diameter using the velocity of sound in the borehole fluid of $1.54 \mathrm{~km} / \mathrm{s}$, chosen by calculating the speed of propagation of the fluid wave in full waveform sonic data (see below). The hole shape data were then fit to an ellipse, from which the total cross-sectional area was computed. The method was calibrated in the section logged 


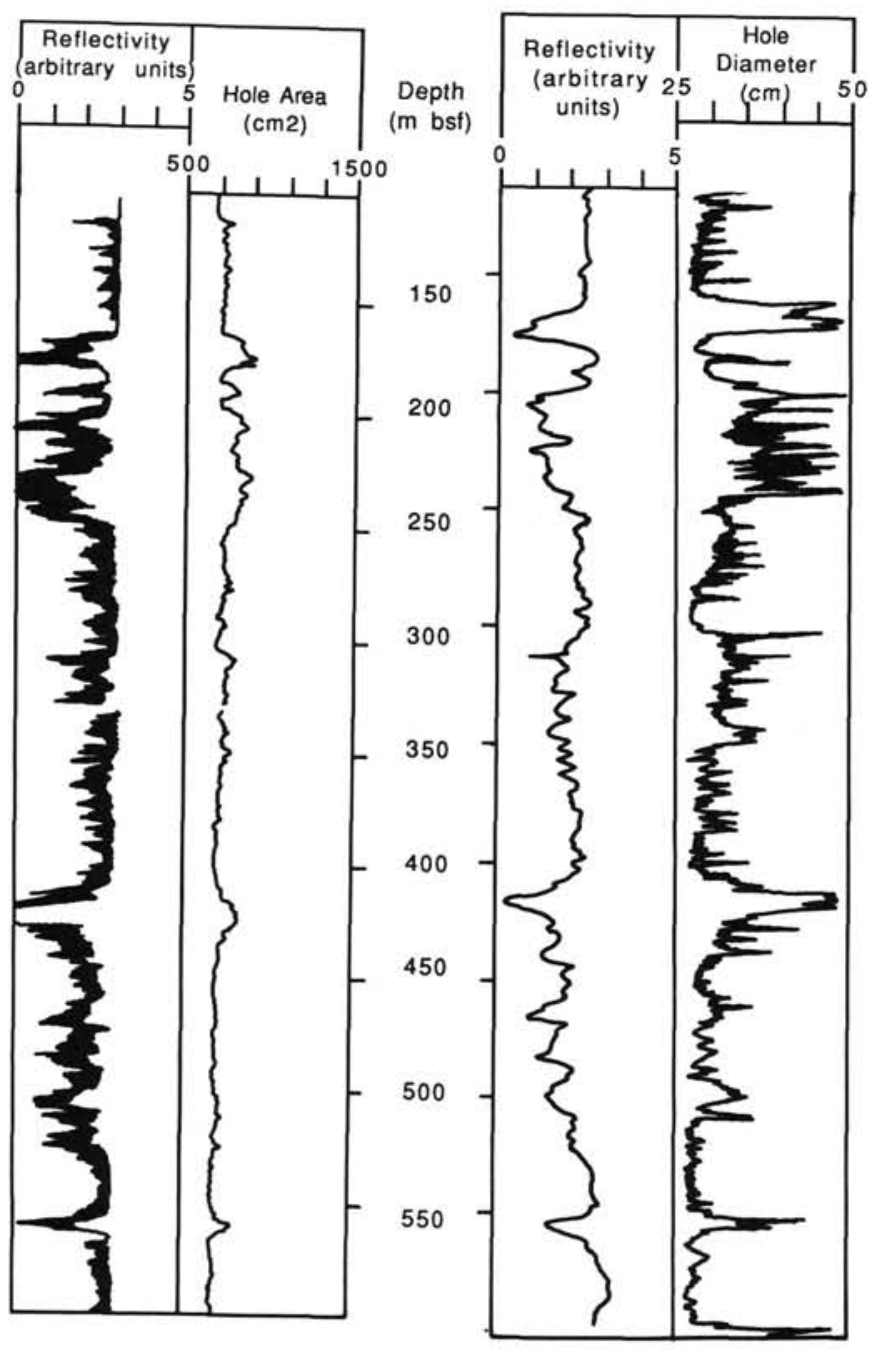

Figure 4. Results of digital analysis of the borehole televiewer data recorded during DSDP Leg 78B. Average reflected amplitude and the borehole cross-sectional area are compared to Hickman et al.'s (1984a) reflectivity analysis and to the two-arm caliper log recorded during Leg 78B.

through casing, using an interior diameter of 11.5 in. (29.2 $\mathrm{cm}$ ); the cross-sectional area of the casing is then $670 \mathrm{~cm}^{2}$. Changes in the BHTV cross-sectional area correlate quite well with those recorded by the two-arm caliper log, although the caliper emphasizes the washouts more. This is because the ellipse fit underestimates the maximum hole diameter, whereas the caliper overestimates the severity of the washout. Thus both measurements provide information on the state of the hole.

\section{GEOPHYSICAL LOGS RECORDED DURING ODP LEG 109}

The principal log data discussed herein are natural gamma radiation, density, porosity, electrical resistivity, and elastic wave velocities. With the exception of the sonic velocities, all of these results were obtained exclusively from commercial logs provided by Schlumberger. A volume-averaged resistivity $\log$ was also determined using a Large Scale Resistivity (LSR) device (Becker, this volume). Aside from the LSR, all of the techniques measure rock properties within a few tens of centimeters of the borehole wall and only provide a vertical cross-section of the in situ material.
Some of the physical properties are measured directly, but most of the data are inferred by indirect measurement (see Serra, 1984, for a detailed description of logging tool design and response). Density is determined by irradiating the formation with gamma radiation and counting the number of gamma rays reaching two detectors further up the tool. The count rate reduction is related to the electron density of the formation, as gamma rays are lost through Compton scattering with electrons. Density is then computed from the measured electron density by assuming that the ratio $\mathrm{Z} / \mathrm{A}$ of atomic number to atomic weight is 0.5 , which is valid for most elements. Porosity is determined by monitoring the interaction between neutrons injected into the formation and neutron scatterers (principally hydrogen atoms). Assuming that all of the hydrogen is in the pore fluid, the decrease in thermal neutron flux between two detectors spaced at different distances from the neutron source is directly related to porosity. Sonic velocity is measured by picking the first arriving refracted wave generated by an acoustic source centered in the borehole. The time difference between arrivals at two receivers divided into the distance between them yields the compressional-wave velocity. In this way, and by measuring both up- and downgoing waves, the measurement can be compensated for hole size variations. The intensity of natural gamma radiation is determined directly, and the concentrations of ${ }^{40} \mathrm{~K}$, Th, and $\mathrm{U}$ are determined by matching the natural gamma spectrum to the known spectra of emission of the respective decay series. Three different Schlumberger resistivity logs were recorded in DSDP Hole 395A; only the spherically focussed $\log (\mathrm{SFL})$ is valid here at all depths, as the other two are induction logs, and are short-circuited by the fluid in the borehole if the formation resistivity exceeds about $200 \mathrm{ohm}-$ m.

The raw log curves are shown in Figure 5. Potassium content from the natural gamma spectra are shown in Track 1, and the natural gamma intensity in API units is in Track 2. The intensity of natural radiation in this hole is extremely low, implying that relatively small amounts of the primary radioactive elements are present in the hole, and thus that little addition or concentration of potassium due to deposition of alteration products has occurred. This agrees with the results of the logs recorded during DSDP Leg 78B (Mathews et al., 1984) and is similar to those obtained by Kirkpatrick (1979) in DSDP Hole 396A. The increase in radioactivity observed by Mathews et al. (1984) in the lowermost portion of the hole is not apparent in these data. Rather, increased radioactivity occurs at regular intervals, as discussed in more detail below.

Apparent neutron porosity is plotted in Track 3. The average value of $20 \%-25 \%$ above 440 mbsf and $20 \%$ below that depth is slightly lower than values measured during DSDP Leg 78B. Porosity and gamma intensity are positively correlated, with trends of decreasing gamma intensity and porosity with depth occurring cyclically over the interval 200-400 mbsf. Low porosities are recorded in the intervals 170-190 mbsf, corresponding to a cored section of flow units, and at 244,277 , and 281-291 mbsf, where porosities as low as 5\% were recorded.

The density log is shown in Track 4 . The highest bulk densities (as high as $2.85 \mathrm{~g} / \mathrm{cm}^{3}$ ) were recorded in the same intervals as the low porosities. Elsewhere the densities averaged about $2.55 \mathrm{~g} / \mathrm{cm}^{3}$, although considerably lower values were recorded within many intervals, generally associated with increased hole size or roughness (see also Figs. 3 and 4).

The resistivities recorded by the SFL are plotted in Track 4. Becker (this volume) discusses the large-scale resistivity (LSR) $\log$ and its comparison to the SFL. The resistivity recorded during Leg $78 \mathrm{~B}$ was considered to be the highest 


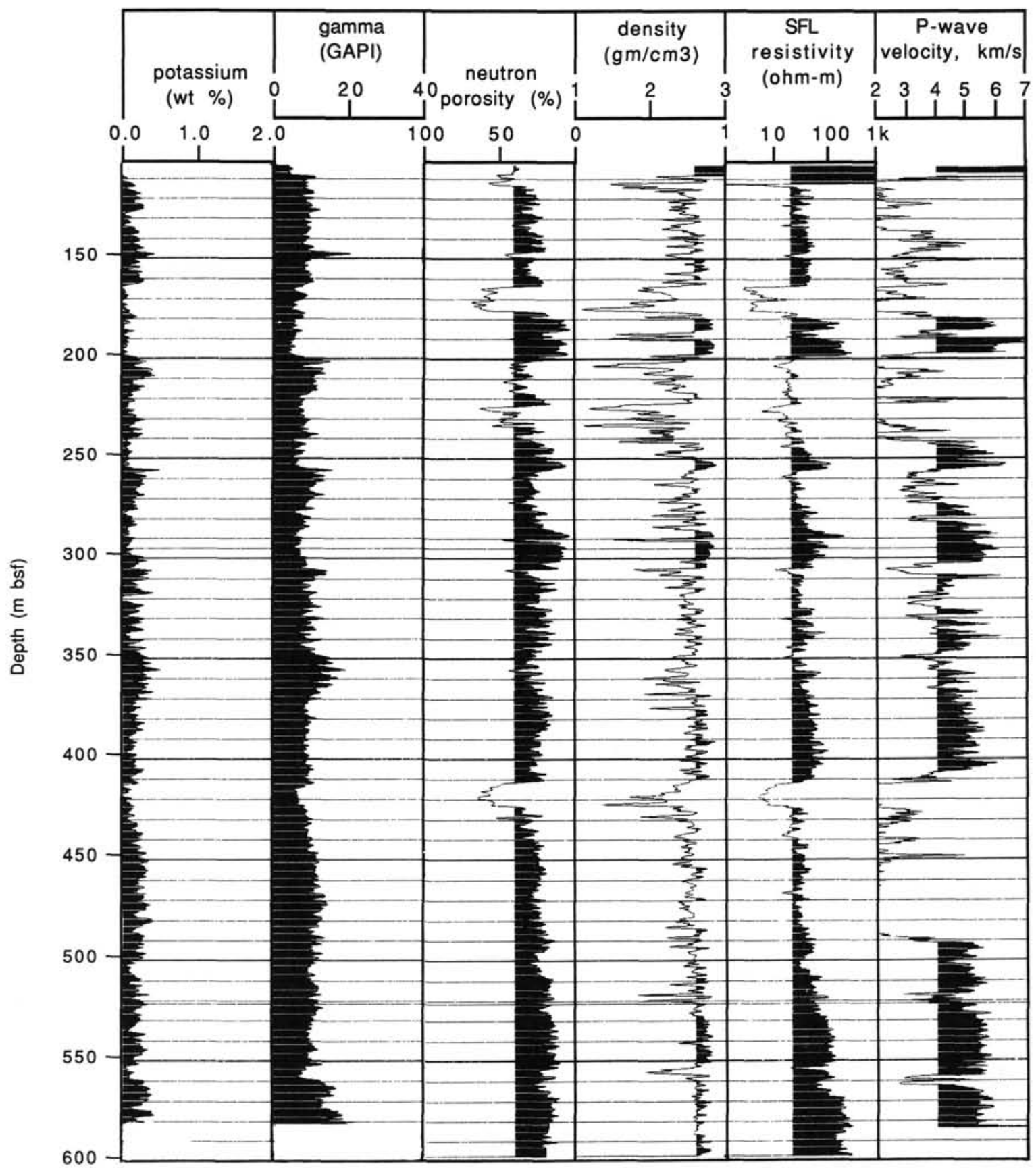

Figure 5. Raw petrophysical logs recorded by Schlumberger during ODP Leg 109 in DSDP Hole 395A. Computed potassium content and total natural gamma radiation, uncorrected neutron porosity (shaded below 40\%), gamma-gamma density (shaded above $2.6 \mathrm{~km} / \mathrm{s}$ ), spherically focussed (SFL) resistivity (shaded above $20 \mathrm{ohm}-\mathrm{m}$ ), and sonic compressional-wave velocity (shaded above $4 \mathrm{~km} / \mathrm{s}$ ) are shown as a function of depth from the bottom of casing to the total logged depth. Casing can be seen by high densities, velocities, and resistivities. The sharp increase in gamma in the lowermost $20 \mathrm{~m}$ is due to logging a formation that had been irradiated by the neutron accelerator in the Schlumberger GST probe.

quality $\log$, and the Leg 109 data are quite similar. Resistivities in this hole are generally above $20 \mathrm{ohm}-\mathrm{m}$, although enlarged sections of the hole have considerably lower values (see also Figs. 3 and 4). Resistivity and porosity generally vary inversely, as expected, with resistivity increasing with decreasing porosity. The cyclic variation in porosity in the interval $200-400$ mbsf is matched by resistivity variations. Below $500 \mathrm{~m}$, resistivity increases systematically to $100 \mathrm{ohm}-$ $\mathrm{m}$ at 535 mbsf. With the exception of a narrow low-resistivity zone at $558 \mathrm{~m}$, resistivity continues to be above $100 \mathrm{ohm}-\mathrm{m}$ to the total logged depth, where it reaches a value of more than 200 ohm-m.

Measured resistivity $\left(R_{m}\right)$ is often normalized by $R_{f}$, the resistivity of the formation fluid, as described by Becker (this volume) after Archie (1942). In this manner variations in formation resistivity due only to changes in the pore fluid properties can be removed before comparisons are made of the formation resistivity of different units. The ratio $R_{m} / R_{f}$ is referred to as the formation factor, $\mathrm{F}$, a dimensionless parameter presumed to be controlled only by the pore structure of 
the formation. In this hole the pore fluid is roughly of seawater composition, and variations in resistivity are controlled only by temperature. The temperatures are tabulated in Shipboard Scientific Party (1988a). Temperatures in the uppermost $385 \mathrm{~m}$ are isothermal $\left(3^{\circ} \mathrm{C}\right)$, below which depth they increase at $0.08^{\circ} \mathrm{C} / \mathrm{m}$ and reach approximately $19^{\circ} \mathrm{C}$ at $585 \mathrm{mbsf}$. Over this temperature range $\mathrm{R}_{\mathrm{f}}$ varies from $0.3 \mathrm{ohm}-\mathrm{m}$ at $3^{\circ} \mathrm{C}$ to 0.2 ohm-m at $19^{\circ} \mathrm{C}$; consequently the conversion from resistivity to formation factor changes the character of the log only slightly.

Elastic-wave compressional velocity from the Schlumberger long-spaced sonic probe is shown in Track 5. The measurements are quite poor in enlarged sections of the hole, but in the lowermost $100 \mathrm{~m}$ the data are excellent and velocities above $5 \mathrm{~km} / \mathrm{s}$ were recorded. Similar velocities were recorded at shallower depths, generally corresponding to the intervals of low porosity and high resistivity and density mentioned above. In the interval 180-200 mbsf velocities are as high as $6 \mathrm{~km} / \mathrm{s}$. Again, cyclic variations in velocity mimic those in porosity and resistivity.

An interesting patterns emerges even in these raw data, as expected for most real materials: porosity is inversely correlated to density, resistivity, and compressional velocity. Furthermore, the cyclic trends in the interval 200-400 mbsf suggest that if most radioactive elements are associated with altered intervals then alteration and porosity are positively correlated. This same correlation shows up in tabulations of core physical properties (e.g., see Broglia and Moos, 1988). A comparison of these data with the caliper logs (Figs. 3 and 4) also reveals a positive correlation between hole size and porosity, which suggests that the data are contaminated by erroneous measurements (see, for example, Broglia and Ellis, 1988). This type of error would result in the observed inverse correlation between porosity and the other log measurements, except that the gamma log should also be inversely correlated to hole size and the velocity should not be affected. As the latter two effects are not observed, it is clear that the measurements reflect real changes in physical properties.

\section{$P$ AND $S$-WAVE VELOCITY FROM SONIC FULL WAVEFORMS}

A digitally recorded full-waveform sonic $\log$ was run during ODP Leg 109 from the casing depth at 112 mbsf to approximately 590 mbsf (Fig. 6). The lowermost section of available hole was not logged, as the 10 -m-long Japanese temperature/ magnetometer sonde was attached to the bottom of the tool during the logging run. The raw data were contaminated by a strong mode traveling along a steel cable within the receiver section of the tool, in part because of the added weight of the Japanese sonde. However, strong compressional arrivals refracted through the formation were recorded within the lowermost $100 \mathrm{~m}$ of the hole, and in isolated sections at shallower depth. These generally correspond to intervals of high density, low porosity, and high resistivity.

To eliminate the tool wave, the data were bandpass-filtered using a $3 \mathrm{~dB} /$ octave bandpass filter, with 3 -dB down points at 8 and $30 \mathrm{KHz}$. The filtered data are shown in Figure 7. Note that the tool wave is largely gone from the data. Unfortunately, the removal of the low frequency tool wave also severely attenuated the shear and Stoneley wave modes, which also propagate at frequencies below that of the compressional wave (e.g., Goldberg and Gant, 1988). Because the spectrum of the borehole modes scales linearly with hole size, the loss of low frequency information is especially critical in Hole $395 \mathrm{~A}$, as the hole is everywhere larger than $25 \mathrm{~cm}$. After high-pass filtering, variations in wave mode amplitude are quite pronounced. Zones with strong, coherent arrivals occur

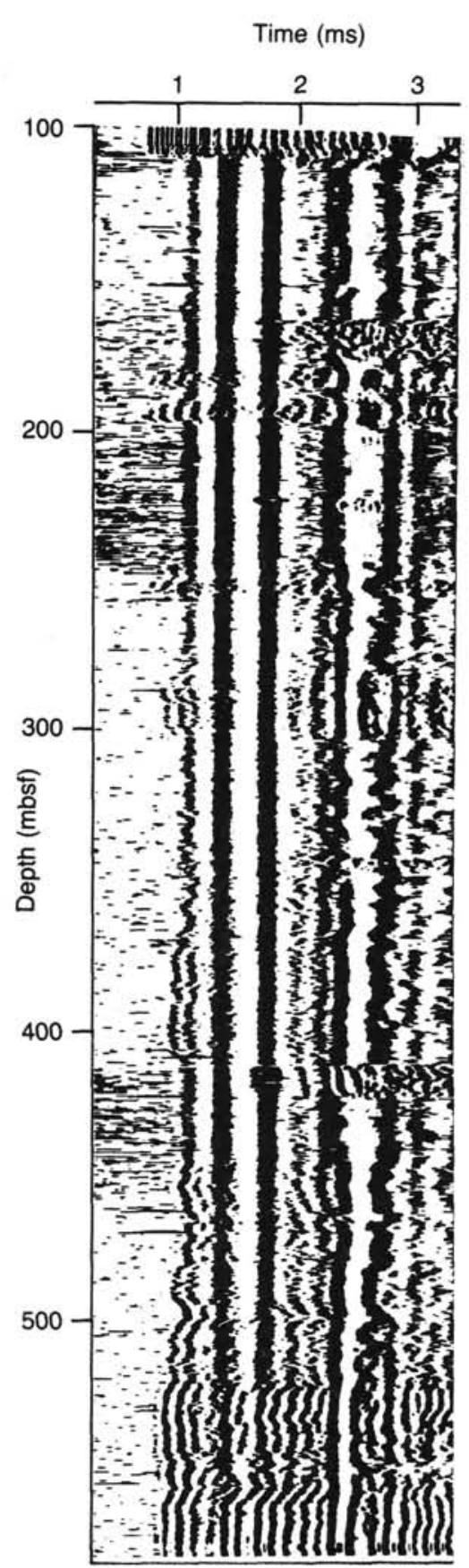
Resistivity
$(\Omega-m)$

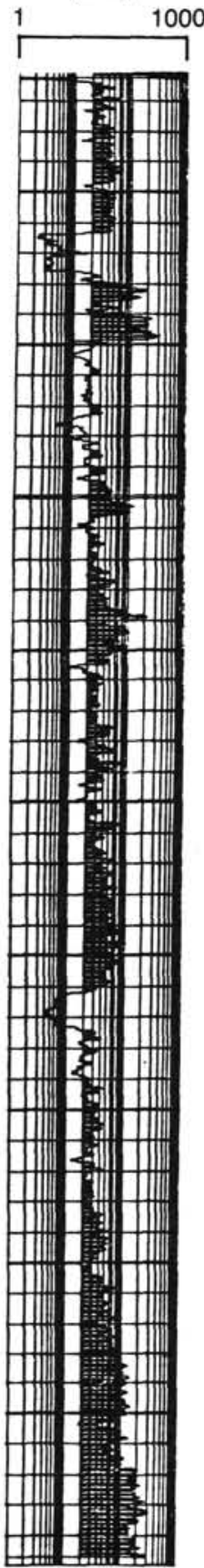

Figure 6. Unprocessed multichannel sonic (MCS) waveforms recorded at receiver 4 (3.6 m from the source) in DSDP Hole 395A during ODP Leg 109. Note the strong consistent low frequency arrival due to propagation along the tool. Higher frequency arrivals refracted along the borehole wall are evident at a number of depths, and are quite strong in the lower $100 \mathrm{~m}$.

at $180-185,190-198,251-261$, and 291-307 mbsf, and the interval from 320 to 420 mbsf is characterized by steadily increasing waveform coherence with depth. Below 420 mbsf the coherence decreases abruptly, then increases with depth, until at 520 mbsf strong ringing arrivals are present. These persist to the total logged depth, with the exception of a narrow zone at 555 mbsf corresponding to a washed-out interval. 


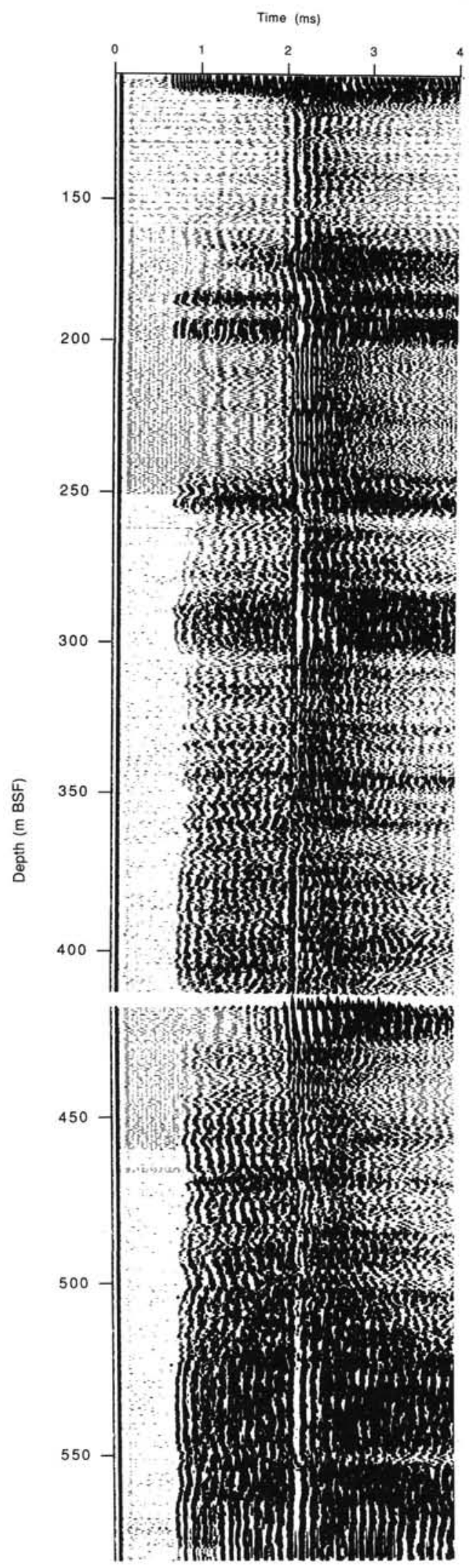

Figure 7. Multichannel sonic waveforms at the nearest receiver ( $3 \mathrm{~m}$ from the source) recorded in DSDP Hole $395 \mathrm{~A}$ after bandpass filtering from 8 to $30 \mathrm{kHz}$. Note that the low frequency tool wave is almost entirely removed. The arrivals refracted along the borehole wall remain, allowing semblance analysis to determine their propagation velocities.
Semblance calculations (Kimball and Marzetta, 1984; Moos, 1988) were made using the six closest receivers, spanning $0.76 \mathrm{~m}$, for velocity ranges from 6 to $3.6 \mathrm{~km} / \mathrm{s}$ (compressional window) and from 4.3 to $1.7 \mathrm{~km} / \mathrm{s}$ (shear window) on the filtered data. The velocities determined in this way were considered meaningful only if the semblance was above 0.4. The results are plotted in Figure 8. Because of the generally poor data quality, the technique does not yield reliable velocities for the entire logged section.

Compressional velocity computed from the filtered data across the entire depth interval ranges from 4.0 to $6.1 \mathrm{~km} / \mathrm{s}$ with an average of $5.0 \mathrm{~km} / \mathrm{s}$. However, significant sections do not yield reliable velocities. The Schlumberger $\mathrm{V}_{p} \log$ data range from 3.1 to $5.8 \mathrm{~km} / \mathrm{s}$ and average $4.5 \mathrm{~km} / \mathrm{s}$ over a somewhat greater percentage of the hole. The MCS results are generally similar to the Schlumberger results in duplicated intervals. In the interval 530-580 mbsf shear-wave velocities were reliable and $\mathrm{V}_{p} / \mathrm{V}_{s}$ averages 1.88.

Seismic velocities near Site $395 \mathrm{~A}$ are consistent with the sonic results. Jacobson et al. (1984) tabulate the velocity results of four seismic surveys, including two near Site 395. Within the uppermost 400 mbsf their velocities average 4.47 $\mathrm{km} / \mathrm{s}$. Hussong et al. (1979) find a higher average velocity of $4.61 \mathrm{~km} / \mathrm{s}$, below a $150-\mathrm{m}$-thick sediment cap. The results of a recent sonobuoy survey are consistent with a constant velocity of $4.12( \pm 0.05) \mathrm{km} / \mathrm{s}$ in the uppermost $250 \mathrm{~m}$ near Site 395 (Purdy, 1987). Primarily due to the fact that the lowest velocity materials are not sampled by the sonic log, the average logged sonic compressional velocity is slightly higher than the above reported seismic velocities.

\section{POROSITY ESTIMATION FROM RESISTIVITY}

The objective of logging at Hole $395 \mathrm{~A}$ is to obtain a vertical profile of the physical properties of young, shallow oceanic crust. The single most important property controlling such measurable quantities as velocity, density, and resistivity is porosity. Also, porosity itself is of considerable interest. Porosity, however, is difficult to measure in DSDP boreholes, as factors degrading log quality (borehole geometry, tool standoff) have the greatest effect on the neutron log. Similarly, density, from which porosity can be calculated by assuming a reasonable grain density, is extremely sensitive to hole conditions. Alternatively, porosity can be estimated from assumed relationships between it and resistivity and/or velocity.

The most important factors controlling the quality of logging data are hole size and borehole wall roughness, and within certain limits logs can be corrected for these effects. Logging data collected on the JOIDES Resolution are further degraded by three effects: ship heave, off-centering, and temperature and pressure. Ship heave introduces oscillatory variations in vertical acceleration of the logging sonde in the hole, which make accurate determination of the depth of the $\log$ measurements extremely difficult. Changes in temperature and pressure with depth change the electrical resistivity of the borehole fluid and can also affect detector characteristics.

Greenberg (1988) presents a very careful discussion of these factors as they affect the logs in Hole 395A. He concludes that the porosity log is completely unreliable. He uses density measurements instead, but only where the hole size is less than $25 \mathrm{~cm}$, and where the density correction term $(\Delta \rho$, which is determined based on differences between the expected count rates at the near and far detectors and their actual value) is less than $0.01 \mathrm{~g} / \mathrm{cm}^{3}$ (for further information see Serra, 1984). Assuming a fixed value for grain density, he then inverts these density values for porosity. From the resultant porosity values and a resistivity log corrected for variations in borehole size, he computes an Archie-type relationship between porosity and resistivity at the depths for 


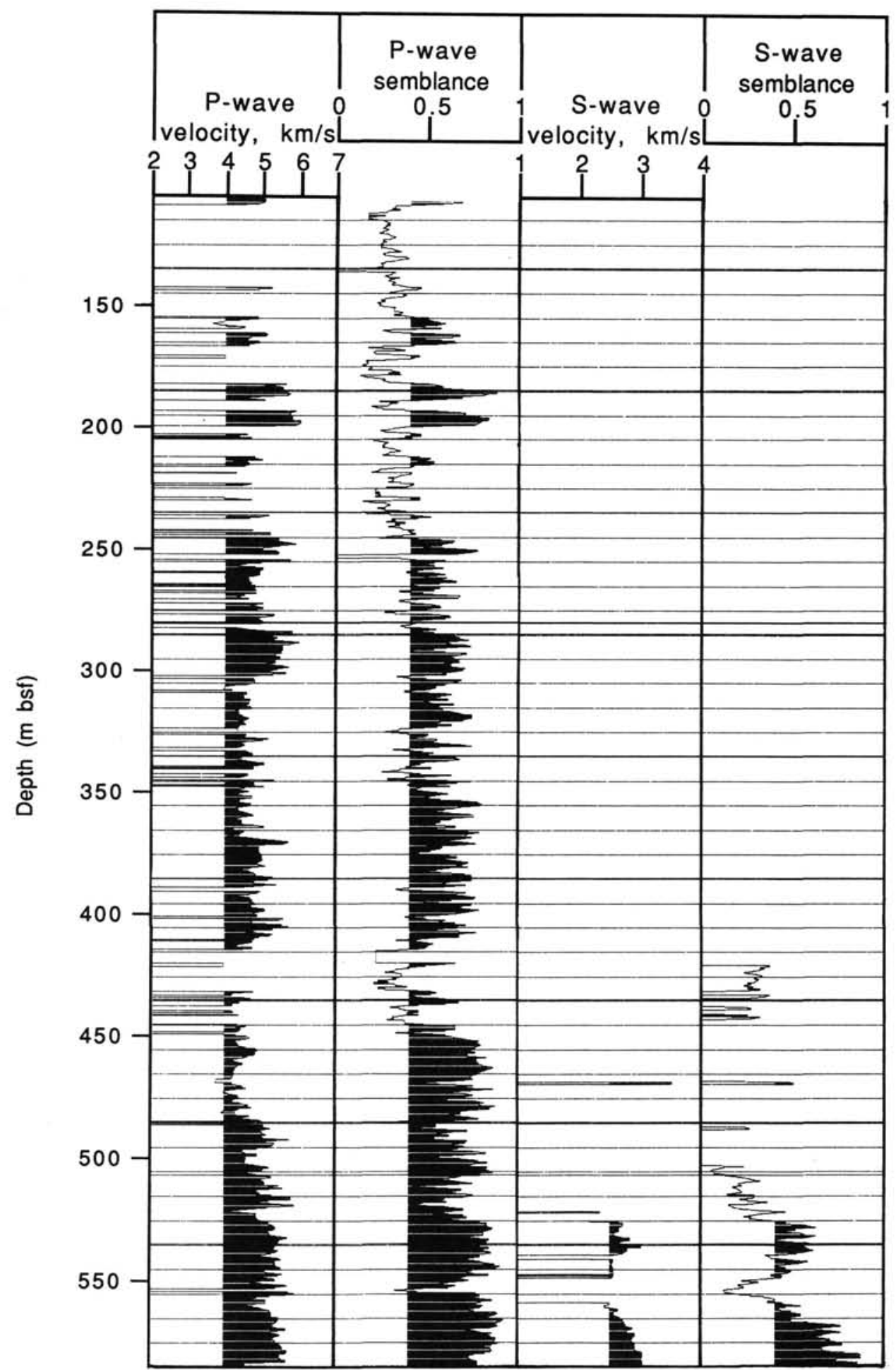

Figure 8. Results of semblance analysis using the nearest six receivers to the acoustical source, spanning a depth interval of $0.76 \mathrm{~m}$. Semblance, which is a measure of waveform coherence, is also shown (shaded above a value of 0.5 ). Velocity results are considered valid if the semblance is above 0.4 . Valid compressional velocities (shaded above $4 \mathrm{~km} / \mathrm{s}$ ) are obtained over more than $70 \%$ of the logged depth, whereas shear velocities (shaded above $2.5 \mathrm{~km} / \mathrm{s}$ ) could be measured only in the lowermost $50 \mathrm{~m}$. 
which both logs are valid (Archie, 1942). He then computes a correlation between caliper and resistivity throughout the total logged depth. Assuming that the correlation is entirely due to hole size, and that none of the hole size variations are due to changes in rock properties, the caliper effect is removed by subtracting that portion of the resistivity variation correlated with hole size. This imperfect assumption is clearly the only possible way of obtaining accurate resistivity data, as exact corrections for resistivity logs in very large holes are not available from Schlumberger. However, some real rock property variations may be obscured in the process. Once this correction is made, an apparent porosity curve can be obtained from the resistivity $\log$, that ideally should be valid throughout the total logged depth.

Rather than computing porosity by assuming an Archietype relationship between corrected resistivity and densityderived porosity, as Greenberg (1988) does, one can compute porosity from velocity using an empirical relationship calibrated by core or other data. As this method is typically employed to estimate porosity from seismic data, the results should be at least qualitatively similar to previous work in the ocean crust (see Orcutt, 1987). The sonic velocities used for this analysis include Schlumberger's logged data and velocities determined from the above analysis of multi-channel sonic data.

\section{POROSITY FROM $P$ AND $S$-WAVE VELOCITIES}

A number of researchers have related velocity to porosity $(\phi)$ using data from laboratory samples. Christensen and Salisbury (1985) found a linear fit to laboratory data for measurements on samples from DSDP Hole 504B where:

$$
\begin{aligned}
& \mathrm{V}_{p}=6.4-9.8 \phi \\
& \mathrm{V}_{s}=3.5-7.0 \phi
\end{aligned}
$$

Hyndman et al. (1984) derived relationships of the following form:

$$
\begin{aligned}
& \mathrm{V}_{p}=6.44-9.61 \phi+7.20 \phi^{2} \\
& \mathrm{~V}_{s}=3.42-6.54 \phi+7.01 \phi^{2}
\end{aligned}
$$

Broglia and Moos (1988) found a relationship between logged velocity and porosity in DSDP Hole 418A, where:

$$
\mathrm{V}_{p}=6.224-7.0 \phi
$$

All of the above relationships are volume-averaging or mixing laws. With the exception of Hyndman's equations, they all have a linear relationship between velocity and porosity. Wyllie et al. (1958) proposed a time-average equation of the form:

$$
1 / \mathrm{V}_{p}=\phi / \mathrm{V}_{\mathrm{f}}+(1-\phi) / \mathrm{V}_{\mathrm{m}}
$$

where $V_{f}$ is the fluid velocity and $V_{m}$ is the zero-porosity matrix velocity. The time-average equation is most successful in predicting the mean velocity of a sequence of layers, as it essentially averages the interval transit-times across each layer to derive an aggregate velocity. As this is a somewhat unrealistic model for a porous medium, the time-average equation is generally not used.

Although no exact relationship has been developed between porosity and velocity, theoretical considerations allow limits to be placed on the range of allowable moduli for a two-phase aggregate material, when the moduli of the compo- nents are known (see Hashin, 1983, or Watt et al., 1976 for a detailed discussion). The so-called Hashin-Shtrickman bounds on bulk modulus are the best possible, but the same cannot be said of those for the shear modulus. Furthermore, it is not clear that the velocities, which involve dynamic moduli, can be calculated from the bounding values of the static elastic moduli. Purdy (1987) has shown that although the available velocity data fall within the Hashin-Shtrickman limits, there is no a priori method for inverting velocity for porosity. This is not surprising, as for a given porosity, it is the pore geometry that determines the velocity of the composite. O'Connell and

\begin{tabular}{lcccc}
\hline & Depth range & \multicolumn{3}{c}{ Porosity (\%) } \\
Log type & (mbsf) & Eq 1 & Eq 2 & Eq 3 \\
\hline$V_{p}$ & $112-606$ & 14 & 17 & 17.5 \\
$V_{p}$ & $112-500$ & 16 & 19.5 & 19.2 \\
$V_{p}$ & $500-606$ & 11 & 13 & 13 \\
$V_{s}$ & $500-606$ & 9 & 6 & - \\
\hline
\end{tabular}

Budiansky (1974) and Toksöz et al. (1976) discuss theoretical relationships between porosity, pore aspect ratio, and elastic properties. Their models allow porosity and pore aspect ratio to be predicted from velocity, if assumptions are made about the distribution and geometry of the individual pores. For the purpose of this discussion, however, empirical relationships are adequate to allow first-order porosity estimates from the velocities.

Compressional wave velocities are sometimes presumed to be insensitive to macroscopic fractures (Serra, 1984), and thus porosities derived from compressional velocities are taken as a measure of the non-fracture-controlled pore volume. Fracture porosity may then be obtained by the difference between the total porosity and the sonic-derived porosity. In this hole there is only the Greenberg (1988) resistivity-derived porosity and the sonic-derived porosity, which may be treated as a minimum estimate for the total porosity. Figure 9 presents the sonic porosities derived from compressional velocities using equations 1, 2, and 3. Average sonic porosities from each model are tabulated below:

As can be seen in Figure 9, apparent sonic porosities range from less than $10 \%$ to more than $25 \%$, and are lowest in the bottom $100 \mathrm{~m}$ of the hole. The different sonic porosity estimators yield porosities in essentially the same range, so I will choose Eq. 1 as the estimator of choice, simply because it is a lower bound on the sonic porosity, which is in turn generally assumed to be a lower bound on total porosity.

\section{DISCUSSION}

The composite log data are plotted in Figure 10. The potassium content (Track 1) and natural gamma (Track 2) logs have been corrected for hole size and temperature. The density curves (Track 3) include Greenberg's (1988) corrected density, as an upper bound, and the raw log curve, as a lower bound. Formation factor (Track 4) is computed from the resistivity log, as described above, using temperature-corrected fluid resistivities. The compressional velocity curve (Track 5) is an aggregate curve including both the Schlumberger and multichannel sonic derived velocities. Where both methods yielded reliable results, the MCS data are used. Also shown in this track are the seismic velocity profile of Jacobson et al. (1984) and compressional velocities measured on core samples (Hyndman et al., 1984). $\mathrm{V}_{p} / \mathrm{V}_{s}$ ratio is presented in Track 6, to emphasize its variation in the lowermost $80 \mathrm{~m}$ of the borehole. The extreme right-hand track shows various porosity curves. Neutron porosity has been corrected for "clay" content, based on the potassium content log, for 


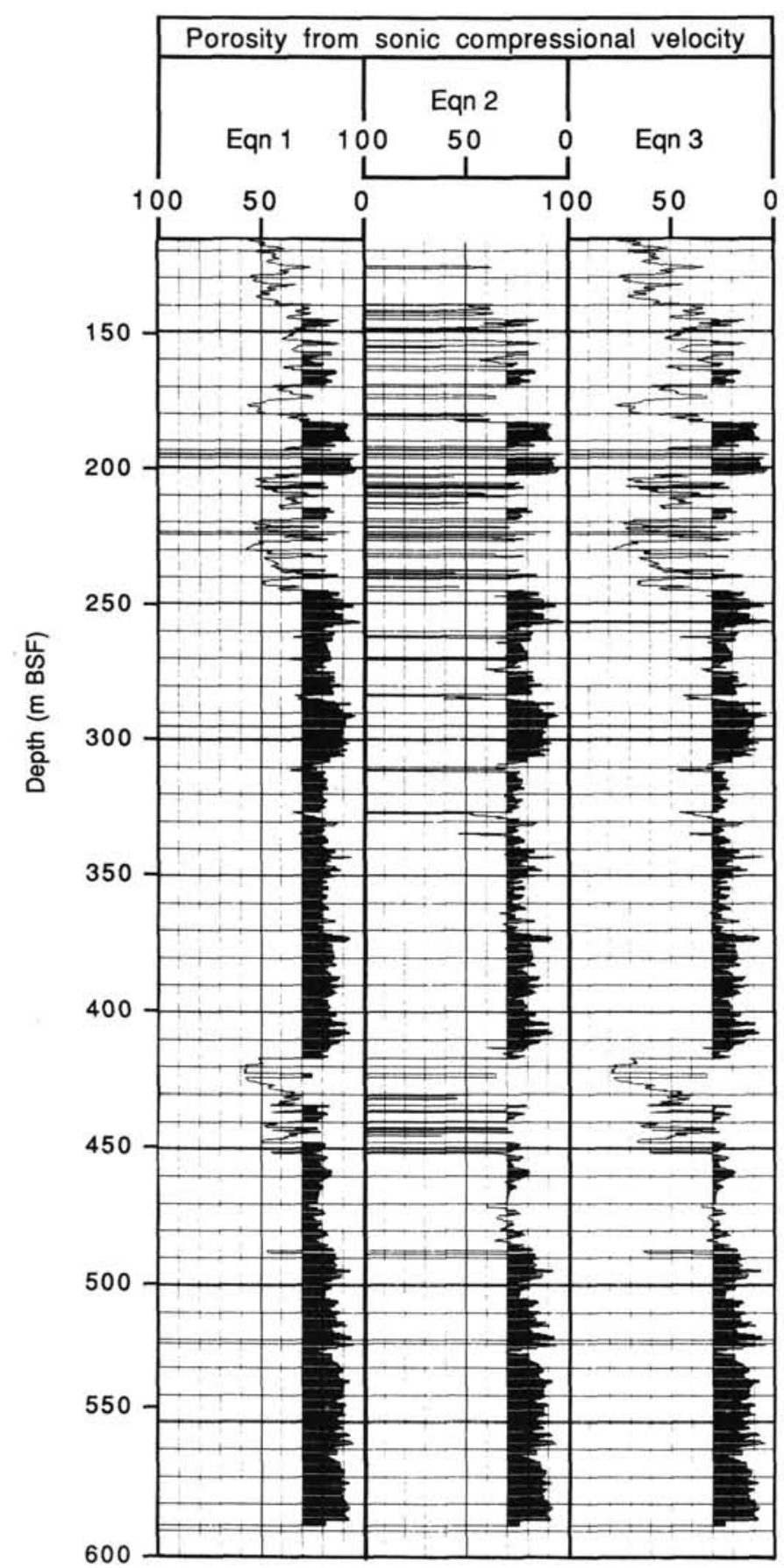

Figure 9. Porosities in percent derived from sonic velocities using the empirical relationships Eq. 1, 2, and 3. In each case the curves are shaded for porosities below $30 \%$.

lithology (see Broglia and Moos, 1988), and for the average hole size. Also shown is porosity calculated from the formation factor (normalized resistivity) using Archie's Law with an exponent $\mathrm{m}=2$ and $\mathrm{a}=1$. Finally, porosity calculated from the sonic compressional velocity log using Eq. 1 is also shown. Shading is applied between neutron porosity and sonic porosity whenever (as is typically the case) the neutron porosity is greater than the sonic porosity.

The geophysical log results are generally quite reasonable for young oceanic crust. Formation factor is generally above 40 , yielding densities above $2.75 \mathrm{~g} / \mathrm{cm}^{3}$ and porosities below
$15 \%$ by Archie's Law. Sonic-derived porosities are generally higher than resistivity-derived porosities. Neutron porosities are generally higher than both sonic and resistivity-derived porosities. Velocities are generally above $4 \mathrm{~km} / \mathrm{s}$ and range as high as $6 \mathrm{~km} / \mathrm{s}$ in numerous narrow intervals. Velocity and resistivity are positively correlated and porosity is inversely correlated to density. In two sections where the hole is badly washed out (170-180 and 416-430 mbsf), the data are not reliable, providing at best a lower bound on density of about $2.5 \mathrm{~g} / \mathrm{cm}^{3}$ and an upper bound on porosity of $25 \%$, both based on an Archie's Law relationship of resistivity to porosity. No velocities were computed in these intervals. Where shear and compressional velocities are meaningful, $\mathrm{V}_{p} / \mathrm{V}_{s}$ is generally about 1.88, although it varies between 1.70 and 2.15 . The average values of these properties are presented in Table 1. In Table 1, the depth ranges are divided into 112-600 mbsf (the entire logged interval), 112-500 mbsf (the uppermost interval), and 500-600 mbsf (the lowermost interval). The dividing line $(500 \mathrm{~m})$ is chosen somewhat arbitrarily as the depth below which formation factor is consistently above 200 .

Figure 10 also shows lithologic columns derived from core analyses (Melson, Rabinowitz, et al., 1979) and from the final $\log$ data. Although small changes in the positions and thicknesses of the various units are indicated in the figure, these variations are within the range allowed by the recovered core; none of the boundaries is shifted more than the length of a cored interval.

Two distinct textural types were recognized in the cores - phyric and aphyric basalts. These two generic types also have quite distinct expressions in the geophysical logs. The phyric units all have characteristic trends in log responses, most easily seen in the gamma logs, that were also recognized by Hyndman and Salisbury (1984). High gamma and potassium content are measured at the top, decreasing toward the base of each unit. Trends can also be seen in the density and formation factor, particularly for Units $\mathrm{P}_{3}$ and $P_{4}$. The contacts between adjacent phyric units can be located to within a few meters based on sharp increases in potassium and gamma at their tops. Interestingly, these trends are mimicked by the velocities determined in the cores, although the lack of good in situ velocities does not allow the observation of a similar trend in those data. This implies that the changes observed in the logs are due at least in part to changes in the properties of the basalt matrix, rather than simply to variations in macrostructure, although such variations might be present. Similar trends are not seen in the aphyric units, although the uppermost $60 \mathrm{~m}$ of $\mathrm{A}_{3}$ has decreasing potassium and increasing formation factor. Interestingly, taken together the same general trend in total gamma is seen in $A_{2}$ and $P_{2}$, but potassium within these units does not vary in the same systematic fashion.

An increase in the potassium content in these basalts is generally recognized to be the result of alteration by interaction with seawater at low temperatures (as discussed by Holmes, 1988). The profiles of potassium content with depth in the phyric units suggest that each of these units was extruded over a relatively short period of time, and remained accessible to the downward flow of seawater for the period between the deposition of each unit. However, the very low concentration of potassium is in sharp contrast to the basalts at similar intervals within the basement at DSDP Hole 418A (Broglia and Moos, 1988; Holmes, 1988). In Hole 418A potassium-rich clays, potassium feldspars, and palagonite contribute the majority of the signal; these formed at low temperatures during a second phase of alteration. By implication, this second phase is not pronounced in DSDP Hole $395 \mathrm{~A}$, either because conditions were not appropriate for its 


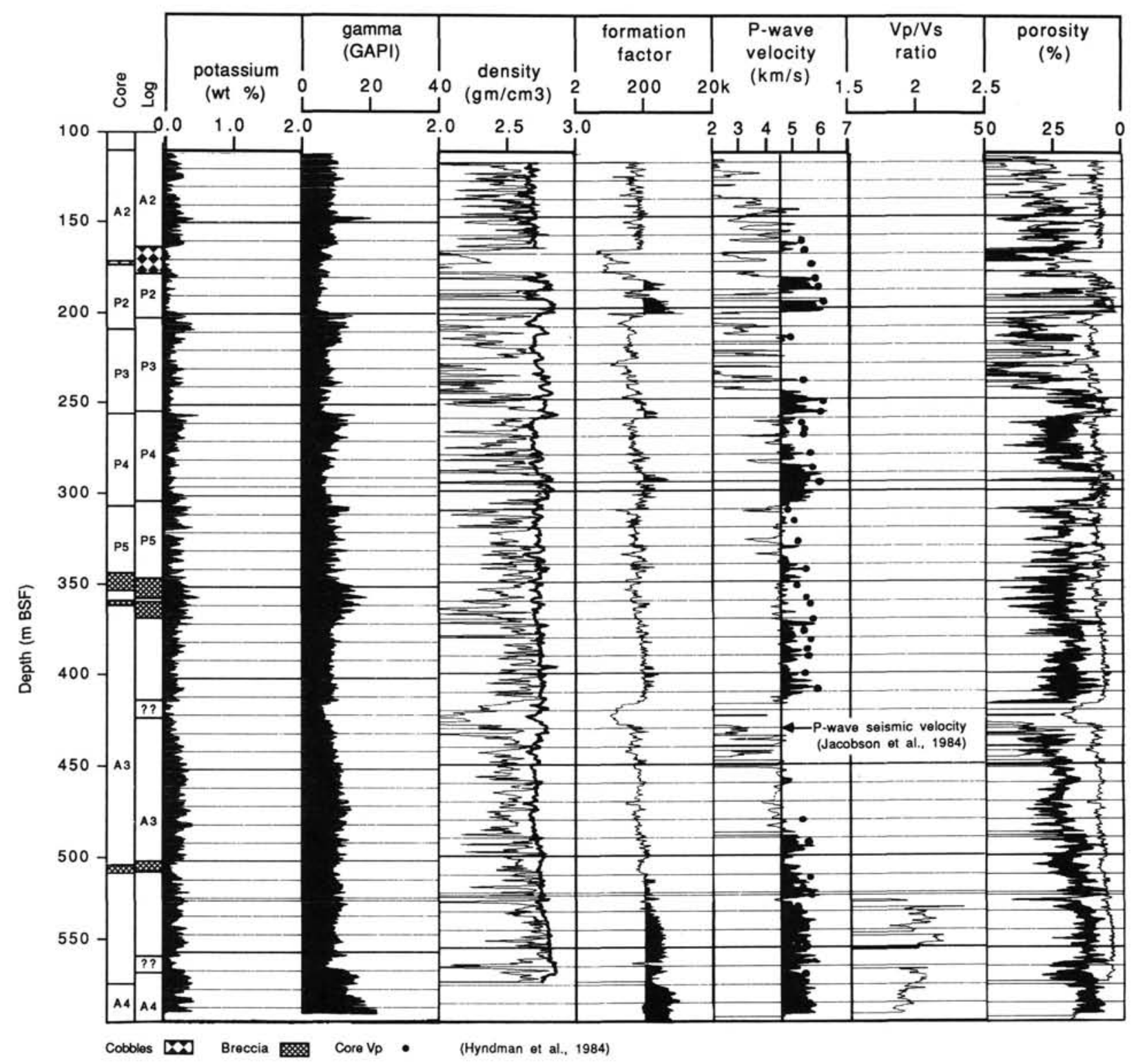

Figure 10. Final composite log data in DSDP Hole 395A. Shown are potassium content in weight percent, natural gamma radiation in API units, raw log and computed (Greenberg, 1988) densities, formation factor (f) from the SFL resistivity log (shaded above 200), composite sonic compressional-wave velocities (shaded above $4.5 \mathrm{~km} / \mathrm{s}$ ), $\mathrm{V}_{p} / \mathrm{V}_{s}$ ratio, and porosities computed from (1) the resistivity log (Greenberg, 1988), (2) the sonic velocities, and (3) the corrected neutron logs. To discriminate the porosity curves, shading is applied between the neutron porosity ( $1 \mathrm{~h}$ curve) and the sonic porosity. Also shown with the sonic velocity are the results of core measurements and the seismic velocity profile at the site. Lithologies determined from core measurements (Melson, Rabinowitz, et al., 1979) are shown along with those inferred from the composite log data. Note that the log-derived thicknesses and positions of the units are within the range allowed by the incomplete core recovery.

development or because not enough time has passed for significant concentrations of these alteration products to have been formed. The former explanation is preferred, as temperatures within these basalts are now too low for this process to continue (e.g., Alt et al., 1985).

Few massive units were recognized in the cores from DSDP Hole 395A (Melson, Rabinowitz, et al., 1984). Massive basalts were observed in the intervals 174-200 mbsf (the upper part of $\mathrm{P}_{2}$ ) and within a narrow interval (257-260 mbsf) at the top of $\mathrm{P}_{4}$. The massive basalts within Unit $\mathrm{P}_{2}$ are characterized by compressional-wave velocities above 5.8 $\mathrm{km} / \mathrm{s}$, approximately equal to laboratory measurements, formation factors above 200 , and densities above $2.8 \mathrm{~g} / \mathrm{cm}^{3}$. Within these units the various porosity indicators converge. These units also had the lowest measured gamma radiation
Table 1. Average log petrophysical properties within DSDP Hole 395A.

\begin{tabular}{lccc}
\hline \multicolumn{1}{c}{ Log type } & $112-600$ mbsf & $\begin{array}{c}\text { Average value } \\
112-500 \mathrm{mbsf}\end{array}$ & $500-600 \mathrm{mbsf}$ \\
\hline $\begin{array}{l}\text { density }\left(\mathrm{g} / \mathrm{cm}^{3}\right) \\
\text { formation factor }\end{array}$ & 2.72 & 2.72 & 2.75 \\
sonic velocity $(\mathrm{km} / \mathrm{s})$ & 181 & 147 & 319 \\
$\quad$ & 4.59 & 4.41 & 5.12 \\
$\quad$-wave & - & - & 2.73 \\
S-wave & $<0.2$ & $<0.2$ & $<0.2$ \\
potassium (wt\%) & 11 & 10 & 14 \\
namma (GAPI) & 26 & 28 & 19 \\
neutron porosity (\%) & 13 & 13 & 12 \\
density porosity (\%) & 9 & 9 & 6 \\
sonic porosity porosity (\%) & 14 & 16 & 11 \\
\hline
\end{tabular}


and potassium content. Using similar discriminators, very thin (less than a few meters thick) massive units can be recognized in the logs within the lower part of $\mathrm{P}_{3}$ at 250 and $258 \mathrm{mbsf}$, the bottom of $\mathrm{P}_{4}(290-295 \mathrm{mbs})$, in $\mathrm{P}_{5}$ at $344 \mathrm{mbsf}$, and in numerous intervals within the upper part of $A_{3}$. These generally correspond to high sonic wave amplitudes (Fig. 7).

Breccias were cored at several depths within DSDP Hole 395A (Melson, Rabinowitz, et al., 1984), and include within the logged section Lithologic Units 13 (344.5-354 mbsf), 15 (360.9-362.2 mbsf), and 17 (504.8-508.7 mbsf). Unit 13 was hydrothermally altered; Unit 15 was described as recrystallized basalt and glass in a carbonate ooze; Unit 17 contained angular fragments in a clay-rich matrix. Each of these units is recognized in the logs, where their thicknesses are somewhat greater than inferred from core recovery. Although the breccias have lower velocities than surrounding materials, Units 13 and 15 have higher potassium, whereas in Unit 17 potassium content is sharply lower. Furthermore, the formation factor in Unit 17 is low, whereas Units 13 and 15 are electrostatically indistinguishable from the surrounding material. These differences are clearly a consequence of differences in alteration, leading to different geochemistry and electrical properties (principally CEC; Pezard and Anderson, in press) between these units. Breccia Unit 6A (DSDP Hole 418A) with high potassium and lower resistivity and velocity (Broglia and Moos, 1988) behaves differently from either of these units.

Three pronounced hole enlargements can be recognized in caliper and BHTV logs of Hole 395A. These occur at 163-178 mbsf, 410-422 mbsf, and 555-560 mbsf. In addition, the Breccia Unit 17 (500-508 mbsf) is also associated with a small caliper enlargement, although the cross-sectional area calculated from the BHTV data is not affected. The first enlargement (163-178 mbsf) can be related to the cobbles cored at the base of $\mathrm{A}_{2}$; by implication this unit may be as much as $15 \mathrm{~m}$ thick. No core lithologic units are associated with the enlargement at 410-422 mbsf, although an increase in fracturing and associated alteration was observed there (Melson, Rabinowitz, et al., 1984). This enlargement is close to the depth at which most of the downward flow enters the formation, based on the temperature gradient which begins to increase just above this depth (Shipboard Scientific Party, 1988a), and may therefore be associated with an underpressured aquifer (see also Becker et al., this volume). The hole enlargement at $555-560$ mbsf is similarly not clearly delineated in the core, although it lies close to the top of Unit $A_{4}$. Based on differences in permeability measured by Hickman et al. (1984b) and Becker et al. (this volume) this interval also may be highly permeable, although it does not actively influence wellbore flow.

The remainder of the cored interval in DSDP Hole 395A is composed of pillow units, with various degrees of fracturing, alteration, and vein filling. As at other DSDP/ODP sites logged to date (Shipboard Scientific Party, 1988b; Salisbury, Scott, et al., 1988), the various primary logs, each of which is generally presumed to be controlled mainly by porosity, yield quantitatively different results. Broglia and Moos (1988) attributed the differences between density/neutron and sonic porosity to the presence in DSDP Hole 418A of macroscopic fractures which do not affect sonic properties. They did not attempt to estimate porosity from resistivity, except to point out that power law relationships such as Archie's Law (Archie, 1942) are quite difficult to apply to delineate fine-scale porosity variations in oceanic basalts, as the parameters are quite variable. Wilkens et al. (1988) studied the relationships between resistivity and velocity in terms of crack properties or porosity structure, and similarly found that pore structure plays a critical role.
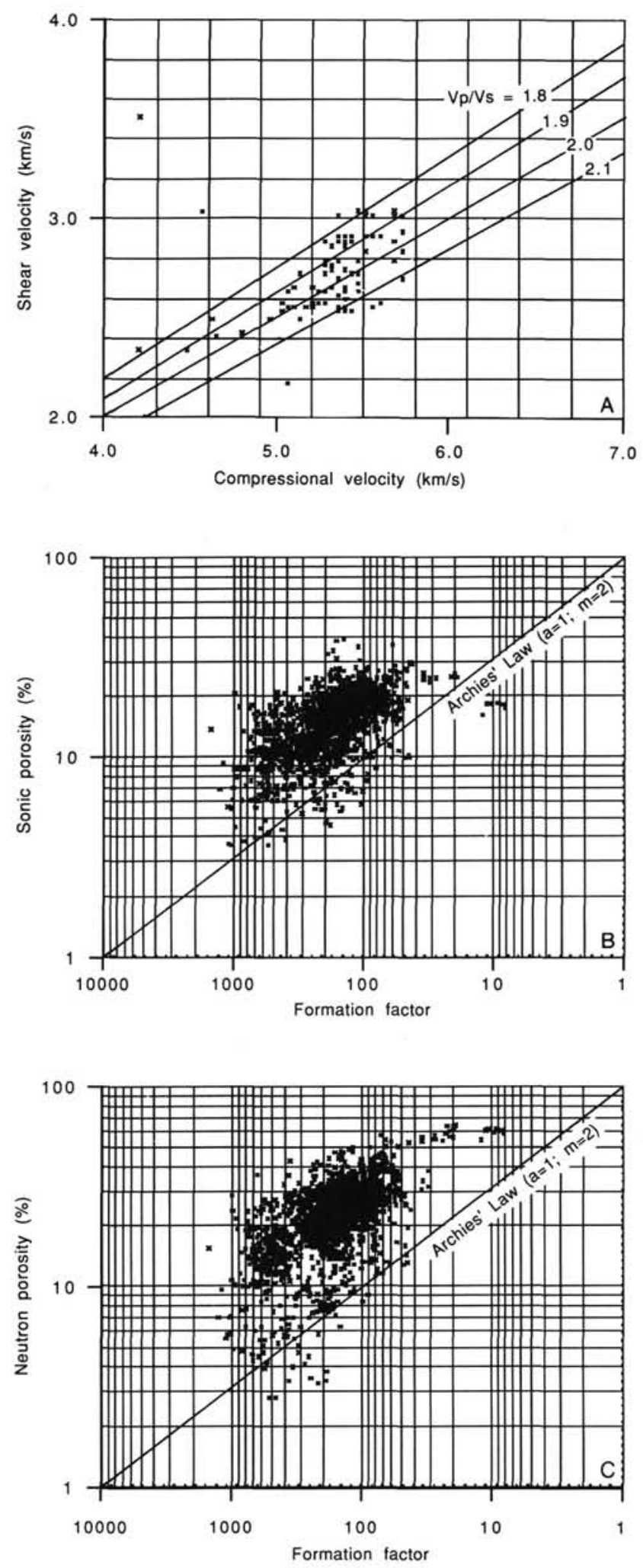

Figure 11. Cross-plots. A. $\mathrm{V}_{p}$ and $\mathrm{V}_{s}$. B. Formation factor and velocity-derived porosity. C. Formation factor and neutron porosity. Also shown in B and C is the Archie's Law (1942) relationship between formation factor and porosity. 
The relationships between the various porosity indicators recorded in DSDP Hole 395A are best illustrated in crossplots, as shown in Figure 11. Figure 11A is a cross-plot of compressional vs. shear velocity, along with lines corresponding to $\mathrm{V}_{p} / \mathrm{V}_{s}$ ratios of $1.8,1.9,2.0$, and 2.1 . The points generally lie above 1.9 , suggesting that there is still a significant degree of crack porosity even in the lowermost $100 \mathrm{~m}$, where in situ velocities approach those measured in laboratory samples. The scatter around this line implies that the crack aspect ratio varies. A systematic trend to lower ratios below the enlarged zone near the top of Unit $\mathrm{A}_{4}$ is seen in the log data (Fig. 10). High formation factors imply poor crack connectivity in this interval, but a similar trend of increasing formation factor with depth is not observed. Most likely the change in velocity ratio is due to nearly complete alteration infilling (with non-conductive materials such as calcite) which becomes volumetrically less important with depth into the unit. The decrease in neutron porosity in the same interval supports this hypothesis and implies that in this interval the log is seeing mostly "bound" water, not open pore space.

The relationship between formation factor and sonic porosities is shown by the cross-plot Figure 11B. Also shown on this figure is an Archie's law relationship with $\mathrm{a}=1$ and $\mathrm{m}=$ 2 . If this is the correct form of the law and the porosity/ velocity relationship chosen (Eq. 1) is correct, all the points should lie along the line. They do not. Sonic porosity is generally higher than resistivity-derived porosity. Figure $11 \mathrm{C}$ shows the Archie-type relationship between corrected neutron porosity and formation factor. Again a "standard" Archie's law does not fit the data: neutron porosities are larger than resistivity would suggest. Becker (this volume) presents resistivity-derived porosities from LSR measurements that are reasonable for these basalts, ranging from $10 \%-15 \%$ in the uppermost pillows to $4 \%$ or less near the bottom of the hole. These are similar to those inferred from the resistivity logderived formation factors presented here, suggesting that the resistivity of large volumes (several tens of cubic meters) is similar to that of the materials close to the borehole wall. The larger values of log sonic porosity are therefore a consequence either of (1) errors in the conversions or (2) differences in the "porosities" sampled by the two measurements.

Pezard et al. (in press) present a careful summary of resistivity/porosity relationships, for which Archie's law type formulae have parameters varying over the range 1-20 for " $a$ " and 1.3 to more than 2.5 for the exponent " $\mathrm{m}$ ". These variations reflect the detailed macrostructural and geochemical composition of the measured materials. For example, a significant component of clay conduction would tend to result in resistivity-derived porosities that are too large. However, the clays would also influence sonic and neutron porosities, depending on their distribution and chemistry. It is clear that understanding the differences between these interpreted porosities is critically important in resolving the properties of oceanic basalts.

The relative magnitude of the porosities shown here is typical of calculations from data collected elsewhere in oceanic crust (e.g., Kirkpatrick, 1979; Cann and Von Herzen, 1983; Salisbury et al., 1985; Broglia and Moos, 1988). Resistivity-derived porosities are generally lower than porosities derived from any of the other log data. Failure to account for the conductivity of hydrous alteration products, a commonly recognized problem (Broglia, pers. comm., 1988), would lead to overestimation of both neutron and resistivity porosities. Although Kirkpatrick (1979) took resistivity and porosity log data at face value, later authors ascribed the differences to errors in the porosity or density logs due to hole conditions, the unspecified presence of neutron absorbers, or poor tool calibrations for basaltic rocks (e.g., Mathews et al., 1984), and therefore relied on Archie's Law for in situ porosities. Similarly, Becker (this volume) uses Archie's Law to derive porosity estimates in lieu of accurate neutron porosities. Test-pit logging results indicate that calibrations are not the problem (Mathews et al., 1985). Lysne (in press) discusses the relative importance of neutron absorbers such as gadolinium (Gd) and provides data to show that they can be a problem in these rocks, requiring corrections to the neutron porosity of 6-10 porosity units, on the order of those applied by Broglia and Moos (1988). The remaining unresolved problem is the poor conditions under which the logs are recorded. These include the extremely rough borehole surface, due to poorly controlled drilling parameters and the brittle nature of shallow pillows, and poor tool contact with the wall of the hole, due to tool design modifications to allow them to fit through the narrow ODP drill pipe. Greenberg et al. (1987) discuss these issues at some length, and tool design efforts are underway to alleviate the problems (Anderson, pers. comm., 1988). Broglia and Ellis (1988) suggest that poor pad contact with the wall of the hole is largely responsible for high neutron porosity readings. In highly altered, $\mathrm{OH}^{-}$bearing basalts, neutron porosities are also too large due to the inclusion of the hydrogen within the $\mathrm{OH}^{-}$ions.

Assuming that both resistivity- and velocity-derived porosities are accurate, the larger sonic porosity could easily be ascribed to a finite amount of unconnected porosity, which influences the sonic $\log$ more than the resistivity log. This space may be partly to completely filled with elastically weak but electrically insulating materials such as low CEC clays. This suggests that excess porosity in the ocean crust is primarily due to voids between pillows, which are partially to completely filled with weak materials, rather than to interconnected fractures. However, the lack of recovery within DSDP Hole $395 \mathrm{~A}$ of significant volumes of these materials suggests that if present they are not capable of being sampled in this environment. Alternatively, a highly anisotropic fracture system with poor vertical connectivity but good horizontal connectivity could give similar results. There is no evidence in the cores for such a microcrack set, and investigating the fracture anisotropy in situ requires other log measurements (see, for instance, Pezard and Anderson, in press).

Recent data suggest that individual pillow units at depth often have quite similar morphologies: a narrow highly porous altered zone at the top, and a zone of intercalated pillows beneath, often having a gradational size change with depth ( $P$. Pezard, pers. comm., 1988). The characteristic log lithostratigraphy in DSDP Hole $395 \mathrm{~A}$ of units ranging in thickness with resistivity and velocity increasing with depth from extremely low values, is consistent with Pezard's observations. Furthermore, Moos (1988) observed narrow zones within thick sequences of pillow basalts with extremely low sonic waveform coherence, corresponding to high porosities and poor core recovery. Finally, in DSDP Hole 395A, enlarged zones at 410-422 and 555-560 mbsf are not discriminated on the basis of core properties. It is quite reasonable, based on the morphology and behavior of pillow-producing flows at mid-ocean ridges, that these intervals are ones in which significant amounts of entrained fluids are trapped within relatively large gaps between pillows. These fluids interact with pillow margins and either are not recovered, or show up in cores as zones of zeolite or smectite infilling between pillows. Trapped fluids can contribute significant amounts of porosity within intervals in the crust, and may not obey simple Archie's Law formalism. The extremely low velocities recorded by Purdy (1987) along the axis of the mid-Atlantic Ridge, and absent immediately outside the ridge axis (coincidentally, near Site 395), may be due to the presence of such 
zones. Evaluation of the detailed permeability structure of young, shallow oceanic crust requires an understanding of these zones, and also requires the hydologic testing of much narrower intervals within these boreholes than have previously been studied.

One of the most important reasons to log DSDP/ODP boreholes is to provide "ground truth" for remote sensing techniques. With this in mind, comparisons between the sonic log velocities presented here and the seismic velocities determined by a variety of researchers near the site $(4.12$ in the uppermost $250 \mathrm{~m}$ by Purdy, 1987; $4.6 \mathrm{~km} / \mathrm{s}$ by Hussong et al., $1979 ; 4.47 \mathrm{~km} / \mathrm{s}$ by Jacobson et al., 1984) are important. Jacobson et al.'s (1984) result is shown in Figure 10 and is close to the average for the entire logged interval. However, more than $50 \%$ of the uppermost $150 \mathrm{~m}$ did not yield reliable MCS compressional-wave velocities; the low velocities in this interval (about $2.5 \mathrm{~km} / \mathrm{s}$ above $130 \mathrm{mbsf}$ and about $3.8 \mathrm{~km} / \mathrm{s}$ between 130 and $250 \mathrm{mbsf}$, excluding the massive units) are derived primarily from the Schlumberger $\log$. If these velocities are correct it suggests that there may be a still-extant zone with velocities characteristic of Layer $2 \mathrm{~A}$, but based on the seismic results this zone must be laterally discontinuous.

\section{CONCLUSIONS}

Analysis of geophysical logs recorded during Leg 109 of the Ocean Drilling Program within the interval 112-606 mbsf in DSDP Hole 395A provides a detailed look at crustal properties at shallow depths in relatively young $(7.3 \mathrm{Ma})$ oceanic crust produced at the slow-spreading mid-Atlantic Ridge. Based on log response, the interval can be divided into two sections. In the uppermost section several thin $(10-50 \mathrm{~m})$ units have very low velocities, resistivities and densities and higher gamma activities at their tops. The porosities decrease and velocities, densities, and resistivities increase with depth in each unit. Average apparent porosities range from $9 \%$ to more than $25 \%$, depending on the computational method. Average compressional velocities are about $4.59 \mathrm{~km} / \mathrm{s}$, although intervals with the lowest velocities are probably not included, as no coherent energy propagates in these intervals. Several flow units have velocities above $5.5 \mathrm{~km} / \mathrm{s}$, porosities less than $10 \%$, and formation factors above 200. Excluding these intervals reduces the velocity average to less than $4.5 \mathrm{~km} / \mathrm{s}$. The lower interval has very consistent properties, with compressional velocity averaging $5.12 \mathrm{~km} / \mathrm{s}$, shear velocities averaging $2.73 \mathrm{~km} / \mathrm{s}$, and $\mathrm{V}_{p} / \mathrm{V}_{s}$ about 1.88 , indicative of the presence of small aspect ratio, possibly filled, cracks. Formation factor is above 400 , and porosity varies between $6 \%$ and $15 \%$, slightly higher than core determinations.

Three different porosity estimates yield quite different average porosities. Greenberg's (1988) porosities, corrected to remove their correlation with hole size, are less than $15 \%$ throughout. Resistivity-derived porosities are more variable, reaching values as high as $20 \%$ in some intervals. Sonic porosities range from $5 \%$ to $25 \%$, and are well correlated to resistivity porosities, but are 2 to 6 porosity units greater on average. Neutron porosities, even after correction for hole size and calibration in basaltic flow units are systematically greater than both sonic- and resistivity-derived porosities.

The difference between sonic and resistivity porosities may be due to the presence in selected intervals of units, typically the tops of pillows, where partially infilled voids between pillows make up the bulk of the porosity. Evidence for these units is also present in DSDP Hole 418A and DSDP Hole 504B. If these are connected across shallow sections of the ocean crust, they could be conduits for fluid flow which explain the very high permeabilities observed in many oceanic crustal drill holes.

\section{ACKNOWLEDGMENTS}

I would like to thank the ODP Leg 109 co-chief scientists, W. Bryan and T. Juteau, and the ODP operations staff, for their support and cooperation during Leg 109 operations. Keir Becker helped coordinate the logging program. The geophysical log data were analyzed using the Terra Sciences Terralog software package. Discussions with P. Pezard improved my understanding of resistivity measurements in oceanic basalts. Reviews by C. Broglia, R. H. Wilkens, and an anonymous reviewer greatly improved the quality of the manuscript. This work was supported by the NSF under the JOI logging contract and OCE 87-04609.

\section{REFERENCES}

Alt, J. C., Laveme, C., and Muehlenbachs, K., 1985. Alteration of the upper oceanic crust: Mineralogy and processes in Deep Sea Drilling Project Hole 504B, Leg 83. In Anderson, R. N., J. Honnorez, K. Becker, et al., Init. Repts. DSDP, 83: Washington (U.S. Govt. Printing Office), 217-247.

Anderson, R. N., Honnorez, J., Becker, K., et al., 1985. Init. Repts. DSDP, 83: Washington (U.S. Govt. Printing Office).

Archie, G. E., 1942. The electrical resistivity log as an ad in determining some reservoir characteristics. J. Petrol. Tech., 5:1-8.

Barton, C. A., 1988. Development of in situ stress measurement techniques for deep boreholes. [Ph.D. dissert.]. Stanford University.

Broglia, C., and Moos, D., 1988. In situ structure and properties of $110 \mathrm{Ma}$ crust from geophysical logs in DSDP Hole 418A. In Salisbury, M. H., Scott, J. H., et al., Proc. ODP, Sci. Results., 102: College Station, TX (Ocean Drilling Program), 29-47.

Broglia, C., and Ellis, D., 1988. Response of the thermal neutron porosity $\log$ to alteration and environmental factors in basaltic rocks from ODP sites EOS, Trans. AGU, 69:1403. (Abstract)

Cann, J. R., Langseth, M. G., Honnorez, J., Von Herzen, R. P., White, S. M., et al., 1983. Init. Repts. DSDP., 69: Washington (U.S. Govt. Printing Office).

Cann, J. R., and Von Herzen, R. P., 1983. Downhole logging at Deep Sea Drilling Project Sites 501, 504, and 505, near the Costa Rica Rift. In Cann, J. R., Langseth, M. G., Honnorez, J., Von Herzen, R. P., White, S. M., et al., Init. Repts. DSDP., 69: Washington (U.S. Govt.. Printing Office), $281-300$.

Christensen, N. 1., and Salisbury, M. H., 1985. Seismic velocities, densities, and porosities of Layer $2 \mathrm{~B}$ and Layer $2 \mathrm{C}$ basalts from Hole 504B. In Anderson, R. N., Honnorez, J., Becker, K., et al., Init. Repts. DSDP, 83: Washington (U.S. Govt. Printing Office), 367-370.

Georgi, D. T., 1985. Geometrical aspects of borehole televiewer images. Trans. 26th Ann. SPWLA Logging Symposium, 1-C.

Goldberg, D., and Gant, W. T., 1988. Shear-wave processing of sonic log waveforms in a limestone reservoir. Geophysics, 53:668-676.

Greenberg, M. L., 1988. Analysis of the geochemical wireline log data acquired in the basalt of DSDP Hole 395A, Ocean Drilling Program Leg 109, [M.S. thesis]. Columbia Univ.

Greenberg, M. L., Anderson, R. N., and Moos, D., 1987. Interpretation, precision, and accuracy of geochemical wireline log data acquired in the basalts of Hole 395A, Ocean Drilling Program Leg 109, EOS, Trans. AGU, 68:1325. (Abstract)

Hashin, Z., 1983. Analysis of composite materials-a survey, J. Appl. Mech., 50:481-505.

Hickman, S. H., Svitek, J. F., and Langseth, M. G., 1984a. Borehole televiewer log of Hole 395A. In Hyndman, R. D., and Salisbury, M. H., et al., Init. Repts. DSDP, 78B: Washington (U.S. Govt. Printing Office), 709-716.

Hickman, S. H., Langseth, M. G., and Svitek, J. F., 1984b. In situ permeability and pore pressure measurements near the midAtlantic Ridge, Deep Sea Drilling Project Hole 395A. In Hyndman, R. D., and Salisbury, M. H., et al., Init. Repts. DSDP, 78B: Washington (U.S. Govt. Printing Office), 699-708.

Holmes, M. A., 1988. Evidence for continuous and discontinuous alteration in DSDP Hole $418 \mathrm{~A}$ basalts and its significance to 
natural gamma-ray log readings. In Salisbury, M. H., Scott, J. H., et al., Proc. ODP, Sci. Results, 102: College Station, TX (Ocean Drilling Program), 136-154.

Hussong, D. M., Fryer, P. B., Tuthill, J. D., and Wipperman, L. K., 1979. The geological and geophysical setting near DSDP Site 395, North Atlantic Ocean. In Melson, W. G., Rabinowitz, P. D., et al., Init. Repts. DSDP, 45: Washington (U.S. Govt. Printing Office), 23-37.

Hyndman, R. D., Salisbury, M. H., et al., 1984. Init. Repts. DSDP, 78B: Washington (U.S. Govt. Printing Office).

Hyndman, R. D., Christensen, N. I., and Drury, M. J., 1984. The physical properties of basalt core samples from Deep Sea Drilling Project Leg 78B Hole 395A. In Hyndman, R. D., Salisbury, M. H., et al., Init. Repts. DSDP, 78B: Washington (U.S. Govt. Printing Office), 801-810.

Hyndman, R. D., and Salisbury, M. H., 1984. The physical nature of young upper oceanic crust on the mid-Atlantic Ridge, Deep Sea Drilling Project Hole 395A. In Hyndman, R. D., Salisbury, M. H., et al., Init. Repts. DSDP, 78B: Washington (U.S. Govt. Printing Office), 839-848.

Jacobson, R. S., Adair, R., and Orcutt, J., 1984. Preliminary seismic refraction results using a borehole seismometer in Deep Sea Drilling Project Hole 395A. In Hyndman, R. D., Salisbury, M. H., et al., Init. Repts. DSDP, 78B: Washington (U.S. Govt. Printing Office), 783-794.

Juteau, T., Bingol, F., Noack, Y., Whitechurch, H., Hoffert, M., Wirrman, D., and Courtois, C., 1979. Preliminary results: mineralogy and geochemistry of alteration products in Leg 45 basement samples. In Melson, W. G., Rabinowitz, P. D., et al., Init. Repts. DSDP, 45: Washington (U.S. Govt. Printing Office), 613-646.

Kimball, C. V., and Marzetta, T. L., 1984. Semblance processing of borehole acoustic array data, Geophysics, 49:274-281.

Kirkpatrick, R. J., 1979. Results of downhole geophysical logging, Hole 396B, DSDP Leg 46. In Dmitriev, L., Heirtzler, J., et al., Init. Repts. DSDP, 46: Washington (U.S. Govt. Printing Office), 401-408.

Lawrence, J. R., Drever, J. J., and Kastner, M., 1979. Low temperature alteration of basalts predominates at Site 395. In Melson, W. G., Rabinowitz, P. D., et al., Init. Repts. DSDP, 45: Washington (U.S. Govt. Printing Office), 609-612.

Lysne, P., in press. Analysis of neutron-porosity-log uncertainties: Ocean Drilling Program Hole 642E. In Eldholm, O., Thiede, J., et al., Proc. ODP Sci. Results, 104: College Station, TX (Ocean Drilling Program).

Mathews, M., Salisbury, M. H., and Hyndman, R., 1984. Basement logging on the mid-Atlantic Ridge, Deep Sea Drilling Project Hole 395A. In Hyndman, R. D., Salisbury, M. H., et al., Init. Repts. DSDP, 78B: Washington (U.S. Govt. Printing Office), 717-730.

Mathews, M. A., Scott, J. H., and LaDelfe, C. M., 1985. Test pits for calibrating well logging equipment in fractured hard-rock environments. SPWLA 26th Ann. Logging Symp.

Melson, W. G., Rabinowitz, P. D., et al., 1979. Init. Repts. DSDP, 45: Washington (U.S. Govt. Printing Office).

Moos, D., 1988. Elastic properties of $110 \mathrm{Ma}$ Oceanic crust from sonic full waveforms in DSDP Hole 418A. In Salisbury, M. H., Scott, J. H., et al., Proc. ODP, Sci. Results, 102: College Station, TX (Ocean Drilling Program), 49-62.
O'Connell, R. J., and Budiansky, B., 1974. Seismic velocities in dry and saturated cracked solids. J. Geophys. Res., 79:5412-5426.

Olhoeft, G. R., 1981. Electrical properties of rocks. In Touloukian, Y. S., Judd, W. R., and Roy, R. F., (Eds.), Physical Properties of Rocks and Minerals, New York (McGraw-Hill), 257-330.

Orcutt, J. A. 1987. Structure of the earth: Oceanic crust and uppermost mantle. Rev. Geophys., 25:1117-1196.

Pezard, P. A., and Anderson, R. N., in press. Morphology and alteration of the upper oceanic crust from in situ electrical experiments in DSDP Hole 504B, In Becker, K., Sakai, H., et al., Proc. $O D P$, Sci. Results, 111: College Station, TX (Ocean Drilling Program).

Pezard, P. A., Howard, J. J., and Lovell, M. A., in press. Clay conduction and pore structure of oceanic basalts from DSDP Hole 504B, In Becker, K., Sakai, H., et al., Proc. ODP, Sci. Results, 111: College Station, TX (Ocean Drilling Program).

Purdy, G. M., 1987. New observations of the shallow seismic structure of young oceanic crust. J. Geophys. Res., 92:9351-9362.

Rhodes, J. M., Blanchard, D. P., Dungan, M. A., Rodgers, K. V., and Brannon, J. C., 1979. Chemistry of Leg 45 basalts. In Melson, W. G., Rabinowitz, P. D., et al., Init. Repts., DSDP, 45: Washington (U.S. Govt. Printing Office), 447-460.

Salisbury, M. H., Christensen, N. I., Becker, K., and Moos, D., 1985. The velocity structure of Layer 2 at Deep Sea Drilling Project Site 504 from logging and laboratory measurements. In Anderson, R. N., Honnorez, J., Becker, K., et al., Init. Repts., DSDP, 45: Washington (U.S. Govt. Printing Office), 529-539.

Salisbury, M. H., Scott, J. H., et al., 1986. Proc. ODP, Init. Repts., 102: College Station, TX (Ocean Drilling Program).

Serra, O., 1984. Fundamentals of well-log interpretation. 1. The acquisition of logging data. Amsterdam (Elsevier).

Shipboard Scientific Party, 1988a. Site 395. In Bryan, W. B., Juteau, T., et al., Proc. ODP, Init. Repts., 109; College Station, TX (Ocean Drilling Program), 175-202.

1988b. Site 504. In Becker, K., Sakai, H., et al., Proc. ODP, Init. Repts., 111; College Station, TX (Ocean Drilling Program), 35-252.

Toksöz, N., Cheng, C. H., and Timur, A., 1976. Velocities of seismic waves in porous rocks. Geophysics, 41:621-645.

Watt, J. P., Davies, G. F., and O'Connell, R. J., 1976. The elastic properties of composite materials. Rev. Geophys. Space Phys., 14:541-563.

Wilkens, R., Schultz, D., and Carlson, R., 1988. Relationship of resistivity, velocity, and porosity for basalts from downhole well-logging measurements in Hole 418A. In Salisbury, M. H., Scott, J. H., et al., Proc. ODP, Sci. Results, 102: College Station, TX (Ocean Drilling Program), 69-75.

Wyllie, M.R.J., Gregory, A. R., and Gardner, G.H.F., 1958. An experimental investigation of factors affecting elastic wave velocities in porous media. Geophysics, 23:459-493.

Zemanek, J., Glenn, E. E., Jr., Norton, L. J., and Caldwell, R. L., 1970. Formation evaluation by inspection with the borehole televiewer. Geophysics, 35:254-269.

Date of initial receipt: 25 August 1988

Date of acceptance: 14 April 1989

Ms 106/109B-150 